\title{
Chapter 9 \\ Nutritional Status of Major Forest Tree Species in Germany
}

\author{
Ulrike Talkner, Winfried Riek, Inge Dammann, Martin Kohler, \\ Axel Göttlein, Karl Heinz Mellert, and Karl Josef Meiwes
}

\subsection{Introduction}

Element contents and ratios in assimilation organs of trees are an essential component of a comprehensive forest condition diagnosis. They allow conclusions about the current nutritional status of trees (Sardans et al. 2016; Mellert et al. 2008; Fiedler and Höhne 1984; Wehrmann 1959). In addition, foliar chemistry can be used as an indicator for the exposure of forest ecosystems to atmospheric pollutants (Ewald 2005; Aber et al. 1989; Heinsdorf et al. 1988). While soil chemical properties indicate the nutrient supply, foliar element contents reflect the nutritional status of the tree itself. The nutritional status of trees is not only determined by the soil nutrient supply but also by the soil nutrient availability and the direct uptake of nutrients from the atmosphere as well as the direct nutrient loss from leaves and needles by leaching. A balanced nutrition of essential main and trace nutrients is a necessary condition for optimal plant growth (Aerts and Chapin 2000). In addition, optimally nourished forest trees are more resistant to external biotic and abiotic stress

\footnotetext{
U. Talkner $(\bowtie) \cdot$ I. Dammann $\cdot$ K. J. Meiwes

Northwest German Forest Research Institute, Göttingen, Germany

e-mail: ulrike.talkner@nw-fva.de; inge.dammann@nw-fva.de; karl-josef.meiwes@nw-fva.de

W. Riek

University for Sustainable Development and Eberswalde Forestry State Center of Excellence, Eberswalde, Germany

e-mail: winfried.riek@hnee.de

M. Kohler

Chair of Silviculture, Albert-Ludwigs University, Freiburg, Germany

e-mail: martin.kohler@waldbau.uni-freiburg.de
}
A. Göttlein · K. H. Mellert
Chair of Forest Nutrition and Water Resources, Technical University Munich, Freising,
Germany
e-mail: goettlein@forst.tu-muenchen.de; karl.mellert@tum.de 
factors than poorly nourished trees (Flückiger and Braun 1999). Pronounced relationships between tree health and nutritional status can therefore be detected (Cape et al. 1990).

Chemical foliar analyses are a substantial part of the National Forest Soil Inventory (NFSI) in Germany. They reveal the current nutritional status of the forests. In addition, comparison of the nutritional data from NFSI I (1987-1992) and NFSI II (2007-2008) contributes significantly to the interpretation of forest ecosystem changes and the effectiveness of both air quality control and forestry stabilization measures (e.g. conversion to mixed-species forests, liming of acidified soils). Furthermore, the extensive data set of the NFSI offers additional opportunities for nutritional diagnoses of conifers by considering ratios between foliar element contents of older and current-year needles.

In this chapter, we evaluate the foliar chemistry of the following tree species: Norway spruce (Picea abies (L.) H. Karst.), Scots pine (Pinus sylvestris L.), European beech (Fagus sylvatica L.) and pedunculate (Quercus robur L.) and sessile oak (Quercus petraea (Matt.) Liebl.). In addition, we assess relationships between foliar chemistry and chemical parameters of the soil. The two oak species were pooled for all analyses. The nutritional diagnoses presented in this chapter are based on tree species-specific threshold values of an integrative assessment system, which was derived by Göttlein (2015). In this meta-analysis, the median threshold value for all assessment systems available in the literature for the major tree species is considered the most probable threshold value. The thresholds at the lower end of the range of normal nutrition are given in Table 9.1.

The evaluation of results depicted several noticeable phenomena for the four major tree species in Germany (Riek et al. 2016) (Fig. 9.1). Luxurious nutrition with nitrogen $(\mathrm{N})$ was observed for all tree species. More than half of Scots pine and oak and more than a quarter of Norway spruce and European beech plots showed foliar $\mathrm{N}$ contents above the normal range. Only $8 \%$ of Norway spruce and $5 \%$ of Scots pine stands were within the range of (latent) $\mathrm{N}$ deficiency. Phosphorus $(\mathrm{P})$ deficiencies were found for all tree species but were most pronounced on European beech plots, with almost two-thirds of plots in the (latent) deficiency range. For all tree species, at

Table 9.1 Threshold values for the four tree species Norway spruce (Picea abies), Scots pine (Pinus sylvestris), European beech (Fagus sylvatica) and oak (Quercus petraea and Q. robur) at the lower end of the range of normal nutrition according to Göttlein (2015)

\begin{tabular}{|c|c|c|c|c|c|c|c|c|c|c|}
\hline Species & $\begin{array}{l}\mathrm{N} \\
\mathrm{mg} \mathrm{g}^{-1}\end{array}$ & $\begin{array}{l}\mathrm{P} \\
\mathrm{mg} \mathrm{g}^{-1}\end{array}$ & $\begin{array}{l}\mathrm{K} \\
\mathrm{mg} \mathrm{g}^{-1}\end{array}$ & $\begin{array}{l}\mathrm{Ca} \\
\mathrm{mg} \mathrm{g}^{-1}\end{array}$ & $\begin{array}{l}\mathrm{Mg} \\
\mathrm{mg} \mathrm{g}^{-1}\end{array}$ & $\begin{array}{l}\mathrm{S} \\
\mathrm{mg} \mathrm{g}^{-1}\end{array}$ & $\begin{array}{l}\mathrm{Fe} \\
\mu \mathrm{g} \mathrm{g}^{-1}\end{array}$ & $\begin{array}{l}\mathrm{Mn} \\
\mu \mathrm{g} \mathrm{g}^{-1}\end{array}$ & $\begin{array}{l}\mathrm{Cu} \\
\mu \mathrm{g} \mathrm{g}^{-1}\end{array}$ & $\begin{array}{l}\mathrm{Zn} \\
\mu \mathrm{g} \mathrm{g}^{-1}\end{array}$ \\
\hline $\begin{array}{l}\text { Picea } \\
\text { abies }\end{array}$ & 13.1 & 1.3 & 4.5 & 2.0 & 0.8 & 1.0 & 42 & 50 & 2 & 20 \\
\hline $\begin{array}{l}\text { Pinus } \\
\text { sylvestris }\end{array}$ & 14.1 & 1.3 & 4.4 & 2.0 & 0.8 & 1.0 & 40 & 40 & 3 & 20 \\
\hline $\begin{array}{l}\text { Fagus } \\
\text { sylvatica }\end{array}$ & 19.0 & 1.2 & 6.0 & 5.0 & 1.0 & 1.5 & 60 & 60 & 5 & 20 \\
\hline $\begin{array}{l}\text { Quercus } \\
\text { petraea } \\
+ \text { robur }\end{array}$ & 20.0 & 1.4 & 6.1 & 5.0 & 1.2 & 1.2 & 70 & 66 & 6 & 15 \\
\hline
\end{tabular}



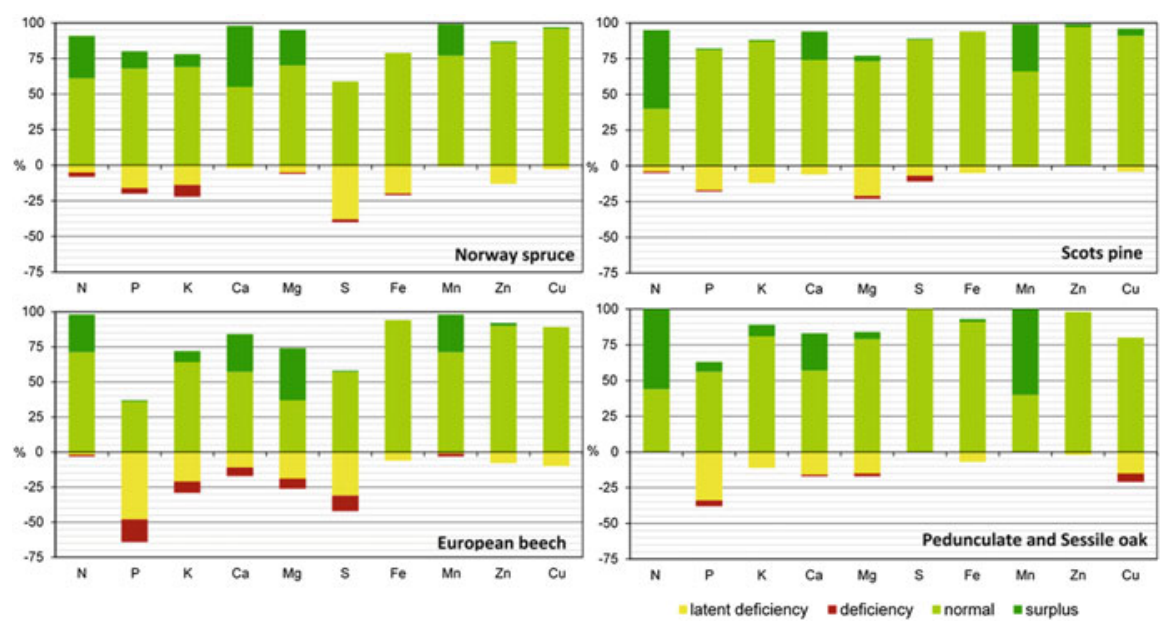

Fig. 9.1 Percentage of NFSI II plots in the four nutritional ranges according to the assessment system of Göttlein (2015) for Germany's major tree species, Norway spruce, Scots pine, European beech as well as pedunculate and sessile oak (pooled together)

least $72 \%$ of all plots showed normal or luxurious potassium $(\mathrm{K})$, calcium $(\mathrm{Ca})$ and magnesium $(\mathrm{Mg})$ nutrition. The sulphur $(\mathrm{S})$ nutritional status was evaluated as normal on most Scots pine and oak plots. However, in the case of Norway spruce and European beech, approximately $40 \%$ of the inventory plots were in the (latent) $\mathrm{S}$ deficiency range. Contents of the trace elements iron $(\mathrm{Fe})$, zinc $(\mathrm{Zn})$ and copper $(\mathrm{Cu})$ were predominantly in the range of normal nutrition for all four tree species. For manganese (Mn), the high proportion of plots with trees in the luxurious range is striking. The results of NFSI II revealed that nutrient deficiencies are more widespread for European beech than for Norway spruce, oak and Scots pine.

Following from the noticeable phenomena found on the NFSI II plots (Fig. 9.1), the aim of this chapter is to test the following hypotheses:

1. Foliar $\mathrm{N}$ contents are related to atmospheric $\mathrm{N}$ deposition.

2. Foliar P contents of European beech are related to the acidification status of the soil and atmospheric $\mathrm{N}$ deposition.

3. Foliar $\mathrm{S}$ contents are related to the sulphate concentration in soil extracts as an indicator for former $\mathrm{S}$ deposition and for sulphate retention capacity of soils.

4. Liming of acidified soils increases foliar $\mathrm{Ca}$ and $\mathrm{Mg}$ contents but may have a negative impact on foliar $\mathrm{K}$ nutrition.

5. Air quality control measures lead to decreased foliar lead contents.

6. The nutritional diagnosis for conifers is improved by considering the ratios between foliar element contents of 2- (Scots pine) or 3- (Norway spruce) yearold needles and current-year needles. 


\subsection{Foliar Nitrogen Nutrition}

Nitrogen is organically bound in plants in the form of proteins as well as amino and nucleic acids. It is an essential component of enzymes involved in metabolic processes, and $\mathrm{N}$ deficiency leads to metabolic disorders as well as reduced plant growth. In contrast, an $\mathrm{N}$ oversupply can either hinder the uptake of other nutrients or lead to nutrient losses from the foliage by canopy leaching, thereby inducing nutrient imbalances of, for example, $\mathrm{K}, \mathrm{Mg}$ or $\mathrm{P}$ in relation to $\mathrm{N}$ (Schulze et al. 1989). In addition, an excess of $\mathrm{N}$ increases the vulnerability to pests and can affect a tree's resistance to frost.

Globally, $\mathrm{N}$ is considered to be the primary factor limiting growth in (near-natural) terrestrial ecosystems (Vitousek and Howarth 1991). Over centuries, biomass export — caused by intensive wood harvesting, litter raking and forest pasturing — has reduced $\mathrm{N}$ stocks of many Central European forest sites, thereby aggravating $\mathrm{N}$ shortage. However, during recent decades, this situation has fundamentally changed due to the atmospheric deposition of nitric oxides from industry and traffic as well as ammonium from agriculture (Gruber and Galloway 2008; Gauger et al. 2008). If $\mathrm{N}$ is no longer a limiting factor, other nutrients may reach a relative deficiency (Mellert and Göttlein 2013). Thus, growth stimulation by N input (Mellert et al. 2008; Spiecker et al. 2012) has the effect that other essential nutrients as well as water must be taken up in larger quantities (de Vries et al. 2006). In addition, direct uptake of $\mathrm{N}$ in the canopy may lead to nutrient losses from the foliage by canopy leaching of, for example, K (Klemm et al. 1989). The resulting higher nutrient and water requirements cannot always be met_-particularly on sites with bedrock that has low levels of base cations - so that the N-based increase in growth may lead to nutritional imbalances involving $\mathrm{N}: \mathrm{Mg}, \mathrm{N}: \mathrm{K}, \mathrm{N}: \mathrm{Ca}$ or $\mathrm{N}: \mathrm{P}$ ratios and more frequent nutrient and water deficiency situations (Aber et al. 1989, 2003). Hence, one of the risk factors Central European forests currently face is the stress caused by high atmospheric $\mathrm{N}$ deposition (Glatzel et al. 1987; Matson et al. 2002; Meesenburg et al. 2016).

The foliar N contents of NFSI II plots stratified by soil substrate groups and current soil acidity levels showed only very weak differences between the various site-specific strata. Even the close relationship expected between humus form and $\mathrm{N}$ nutrition was nearly non-existent. This suggests that $\mathrm{N}$ compounds resulting from atmospheric deposition and available to plants supersede the influence of sitespecific factors on $\mathrm{N}$ nutrition.

The fact that $\mathrm{N}$ deposition contributes to forest $\mathrm{N}$ nutrition was shown by the significant albeit weak linear relationship between $\mathrm{N}$ deposition and foliar $\mathrm{N}$ nutrition (Fig. 9.2 and Table 9.2).

In contrast to $\mathrm{N}$ deposition in Germany, the regional distribution of the tree species-specific $\mathrm{N}$ nutrition ranges in Germany showed only weak spatial patterns (Figs. 9.3 and 9.4). Most Scots pine and Norway spruce stands with normal N supply or even (latent) $\mathrm{N}$ deficiency were located in the north-eastern lowlands (Brandenburg, Saxony), the southern Black Forest and in Rhineland-Palatinate. In all other parts of Germany, foliar N nutrition was predominantly luxurious or normal. 
Fig. 9.2 Scatter plot of Norway spruce, Scots pine, European beech as well as pedunculate and sessile oak (pooled together) foliar $\mathrm{N}$ content in relation to total $\mathrm{N}$ deposition

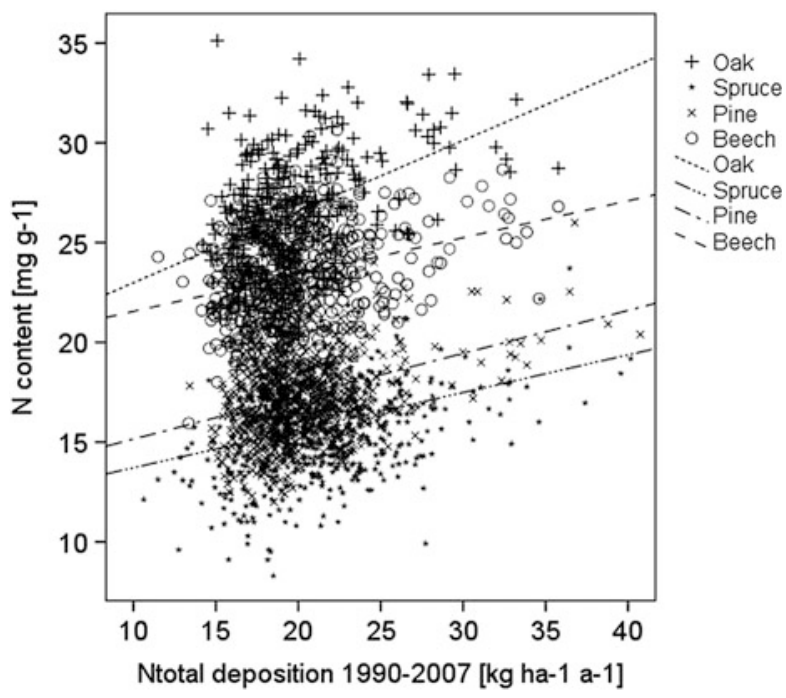

Table 9.2 Parameters of the linear regression between foliar $\mathrm{N}$ content and total $\mathrm{N}$ deposition shown in Fig. 9.2: foliar $\mathrm{N}$ content $=a *$ total $\mathrm{N}$ deposition $+b$

\begin{tabular}{l|l|l|l}
\hline & $a$ & $b$ & $R^{2}$ \\
\hline Norway spruce & 0.189 & 11.83 & $0.11^{* *}$ \\
\hline Scots pine & 0.215 & 13.00 & $0.12^{* *}$ \\
\hline European beech & 0.185 & 19.71 & $0.07 * *$ \\
\hline Pedunculate and sessile oak & 0.357 & 19.42 & $0.18^{* *}$ \\
\hline$* p<0.05 ; * * p<0.01 ; * * * p<0.001$
\end{tabular}

In addition to absolute foliar $\mathrm{N}$ contents, the relation of $\mathrm{N}$ to other nutrient elements can be used to evaluate nutrient imbalances (Flückiger and Braun 2003; Mellert and Göttlein 2012). In principle, a good nutritional state exists when the element contents are sufficient and present in a balanced relationship. Deviations from the reference values for "harmonic" element ratios can indicate possible imbalances in the nutrient supply.

With regard to a balanced nutrition, we found that high $\mathrm{N}$ to nutrient ratios were primarily associated with low values for each of the elements $\mathrm{Mg}, \mathrm{P}, \mathrm{K}$ and $\mathrm{Ca}$ (Fig. 9.5). In contrast, high foliar $\mathrm{N}$ contents did not automatically result in high ratios (Fig. 9.6). For stands with an $\mathrm{N}$ oversupply, very narrow as well as very high ratios occurred for all tree species. Only the highest individual values of the element ratios were generally associated with an exceptionally high level of $\mathrm{N}$ nutrition. Thus, no clear causal relationship between $\mathrm{N}$ surplus and disturbances to nutrient uptake could be derived.

Based on Fig. 9.5 and for the other main elements as well, it is clear that latent element deficiencies are associated with specific element ratios. In order to derive threshold ratios that lead to element deficiencies, the relationships between elements and element ratios were determined using smoothing functions in SPSS according to the LOESS method (Jacoby 2000). Subsequently, the individual intersection of the 


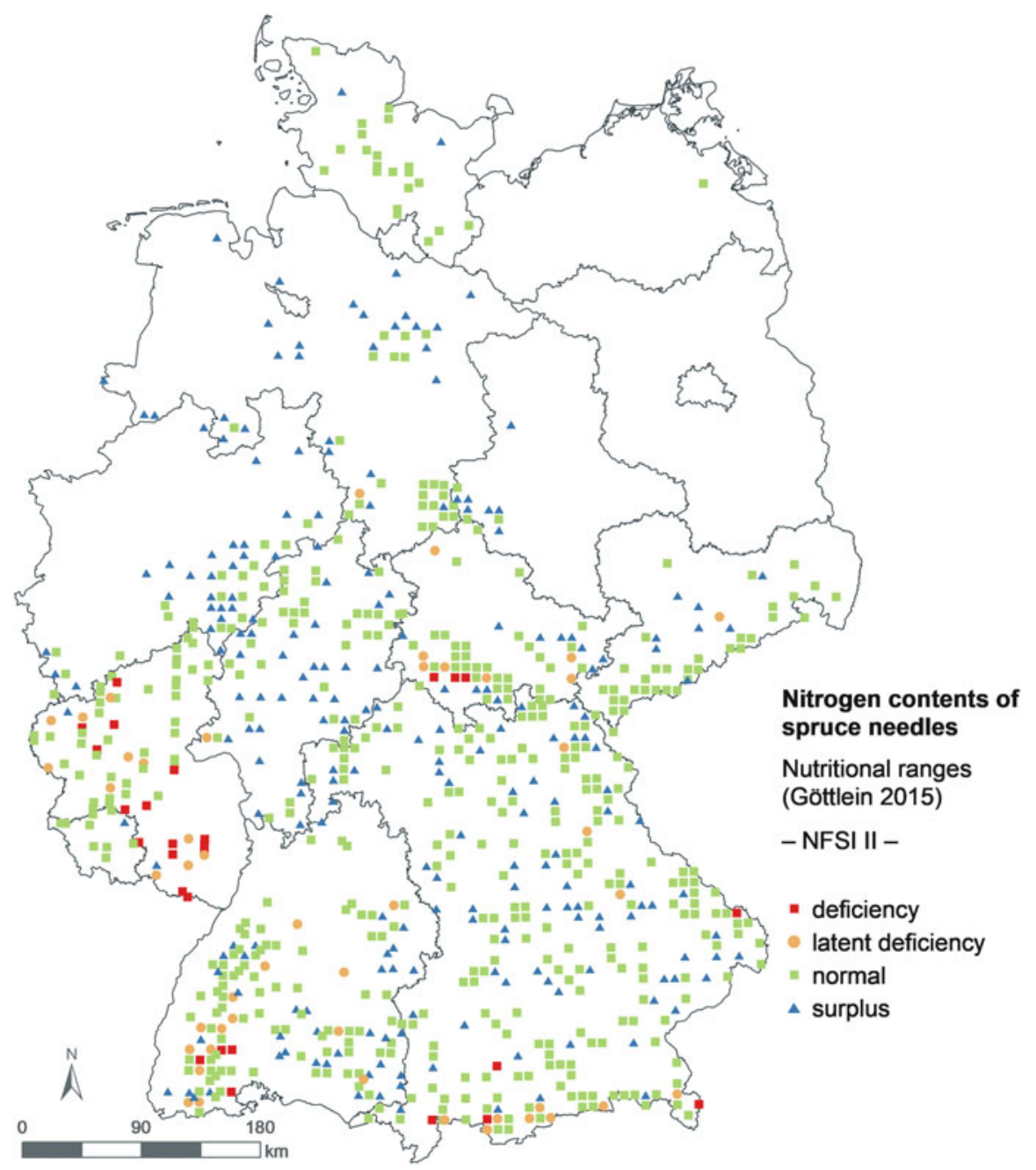

Fig. 9.3 Regional distribution of foliar nitrogen nutrition ranges for Norway spruce

fitted curve with the horizontal borderline between normal nutrition and latent deficiency was determined. The threshold values of $\mathrm{N}$ ratios calculated in this way are shown in Table 9.3. On a statistical average, exceeding these values resulted in latent deficiencies of the respective element.

The $\mathrm{N}: \mathrm{Mg}, \mathrm{N}: \mathrm{P}$ and $\mathrm{N}: \mathrm{K}$ ratios empirically derived from the NFSI data were almost identical to the values derived by van den Burg and reported by Mellert and Göttlein (2012). In general, the thresholds in Table 9.3 are slightly higher. However, the thresholds of Flückiger and Braun (2003) for Norway spruce and European beech are similar. Imbalanced $\mathrm{N}$ ratios can lead to an increased risk of possible infestation by harmful insects (e.g. Flückiger and Braun 2003). In order to avoid 


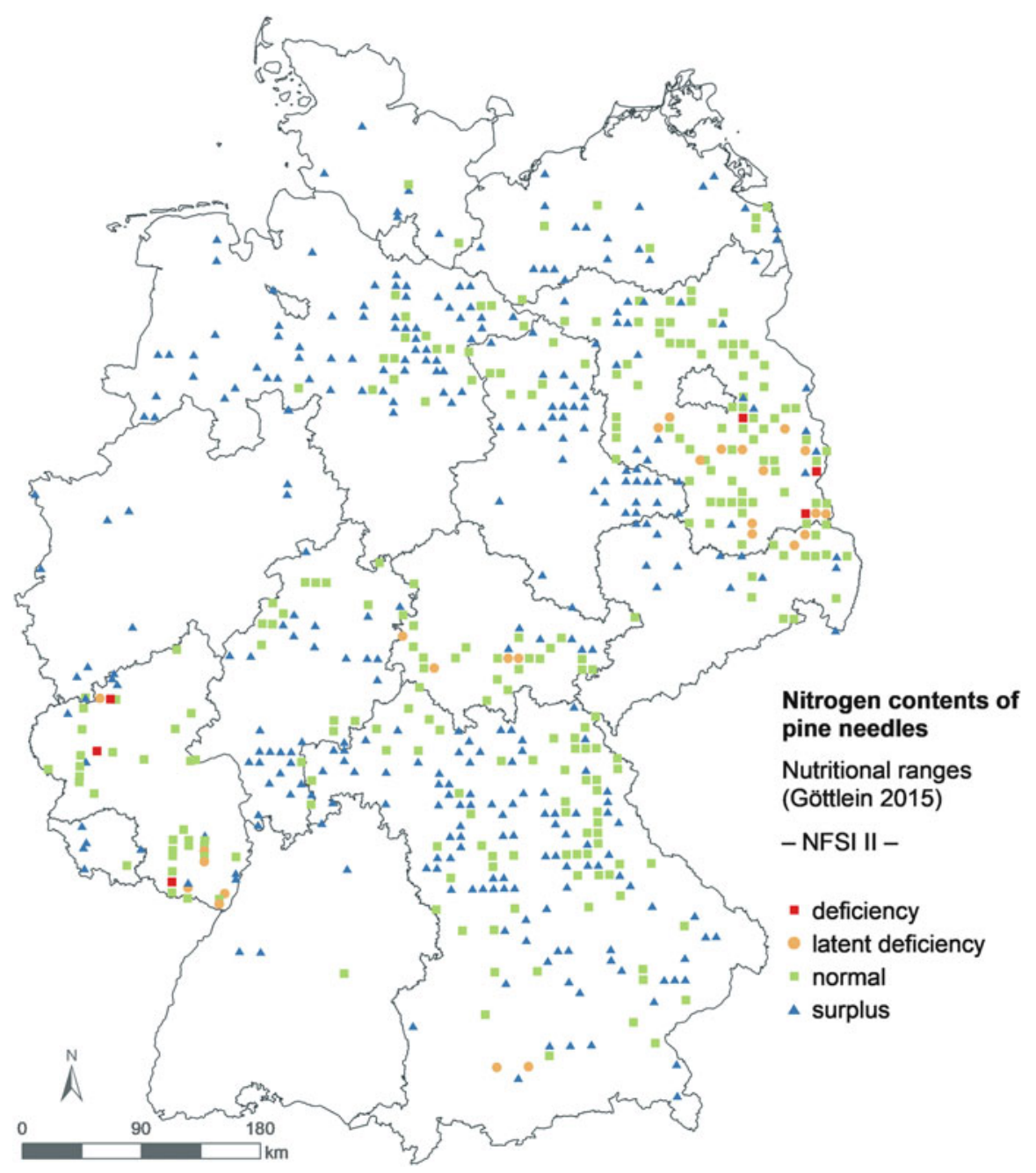

Fig. 9.4 Regional distribution of foliar nitrogen nutrition ranges for Scots pine

values clearly above the thresholds given in Table 9.3, more favourable element ratios may be achieved by soil protection liming, suitable fertilization measures or reduction of atmospheric $\mathrm{N}$ deposition. 


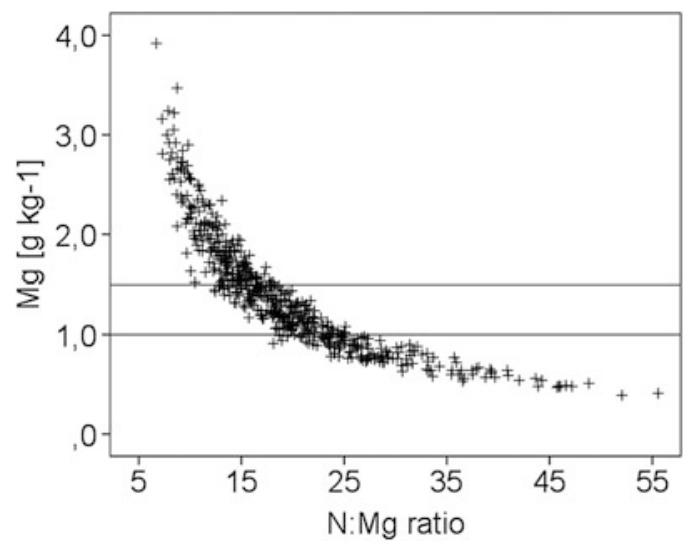

Fig. 9.5 Relationship between foliar $\mathrm{Mg}$ content and foliar $\mathrm{N}: \mathrm{Mg}$ ratio in European beech; horizontal lines mark the normal range for Mg according to Göttlein (2015), i.e. values below the lower line indicate latent $\mathrm{Mg}$ deficiency

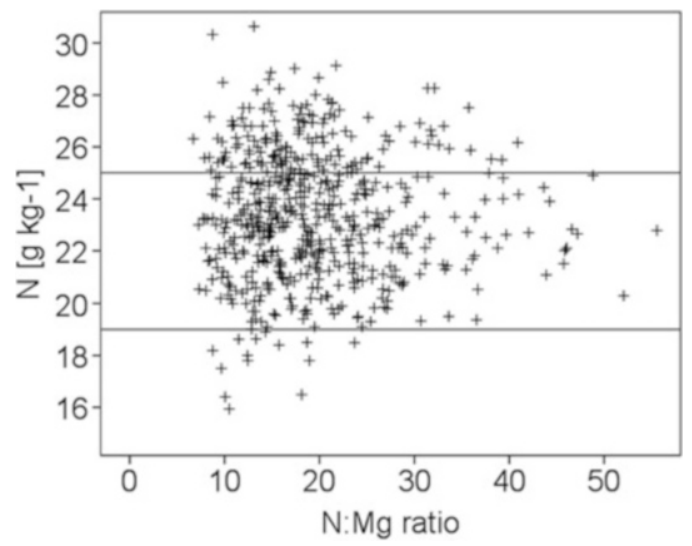

Fig. 9.6 Relationship between foliar N content and foliar N:Mg ratio in European beech; horizontal lines mark the normal range for $\mathrm{N}$ according to Göttlein (2015), i.e. values below the lower line indicate latent $\mathrm{N}$ deficiency

Table 9.3 Critical $\mathrm{N}$ ratios derived from the NFSI II data, which correspond to a latent element deficiency when exceeded

\begin{tabular}{l|l|l|l|l}
\hline & Norway spruce & Scots pine & Pedunculate and sessile oak & European beech \\
\hline $\mathrm{N}: \mathrm{Mg}$ & 22.0 & 22.8 & 23.5 & 23.5 \\
\hline $\mathrm{N}: \mathrm{P}$ & 12.2 & 14.2 & 19.8 & 19.7 \\
\hline $\mathrm{N}: \mathrm{K}$ & 3.6 & 4.3 & 4.5 & 4.0 \\
\hline $\mathrm{N}: \mathrm{Ca}$ & 7.8 & 8.9 & 5.6 & 4.7 \\
\hline
\end{tabular}




\subsection{Foliar Phosphorus Nutrition of European Beech}

Foliar $\mathrm{P}$ nutrition of European beech is deficient across large areas of Europe (de Vries et al. 2000) and has decreased over the past 20 years (Talkner et al. 2015). Several factors may lead to P deficiency: (1) excessive $\mathrm{N}$ deposition, (2) climate change and (3) tree physiology. (1) $\mathrm{N}$ deposition influences foliar $\mathrm{P}$ nutrition primarily by negatively influencing mycorrhizal symbioses (Nilsson and Wallander 2003) but also through increased growth leading to unbalanced foliar nutrition (Nihlgård 1985; Aber et al. 1998). (2) Elevated atmospheric $\mathrm{CO}_{2}$ concentrations as well as increased temperatures appear to increase the C:P ratio in plants (Sardans et al. 2012). In addition, drought events might decrease $P$ contents in European beech trees (Peuke and Rennenberg 2004). (3) More frequent and more intense fructification events (Övergaard et al. 2007; Piovesan and Adams 2001) may deplete $P$ reserves in trees when the mineralization of $P$ from seeds and seed capsules is slow (Khanna et al. 2009) or seeds are eaten and displaced by mice and birds (Burschel et al. 1964). Foliar $\mathrm{P}$ contents represent a good indicator for plant availability of $\mathrm{P}$ at a site, since up to now, no single extraction method has been developed that can adequately quantify plant-available $\mathrm{P}$ in forest soils.

In Germany, the results of NFSI II have revealed that the foliar P content of $60 \%$ of European beech plots is either within the latent deficiency or the deficiency range (see Fig. 9.1). Foliar P contents tended to decrease between NFSI I and NFSI II. This finding is in accordance with results from other parts of Europe (de Vries et al. 2000; Talkner et al. 2015).

The foliar $\mathrm{P}$ content was not related to the soil $\mathrm{pH}$ value on NFSI II plots (Fig. 9.7). One would expect the highest $\mathrm{P}$ availability and therewith the highest foliar $\mathrm{P}$ contents on soils with intermediate $\mathrm{pH}$ values. In calcareous soils high in $\mathrm{pH}$,

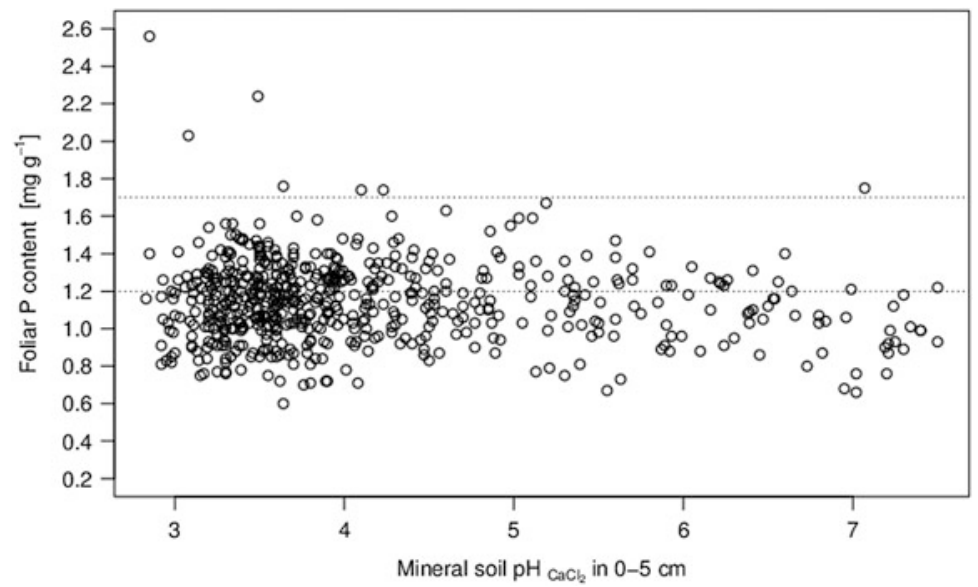

Fig. 9.7 Foliar $\mathrm{P}$ content versus $\mathrm{pH}$ in $\mathrm{CaCl}_{2}$ in $0-5 \mathrm{~cm}$ soil depth at European beech plots; horizontal dashed lines mark the normal range for $\mathrm{P}$ according to Göttlein (2015), i.e. values below the lower line indicate latent $\mathrm{P}$ deficiency 

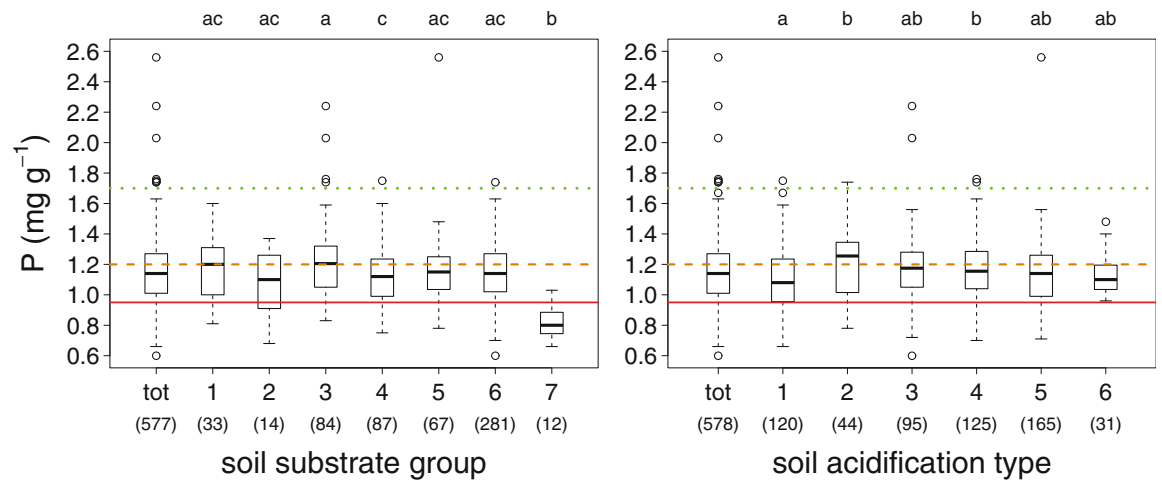

Fig. 9.8 Foliar $\mathrm{P}$ content of different soil substrate groups (left) and soil acidification types (right) at European beech NFSI II plots; horizontal dashed lines mark the nutritional ranges for P according to Göttlein (2015); tot: all groups/types taken together; soil substrate groups: ${ }^{1}$ soils from base-poor unconsolidated sediment, ${ }^{2}$ soils of alluvial plains, ${ }^{3}$ loamy soils of the lowland, ${ }^{4}$ soils from weathered carbonate bedrock, ${ }^{5}$ soils from basic-intermediate bedrock, ${ }^{6}$ soils from base-poor hard bedrock, ${ }^{7}$ soils from the Alps; for definition of soil acidification types, see Chap. 2; different letters above the boxes depict significantly different foliar P contents

Ca phosphates of low solubility are formed; hence, $\mathrm{P}$ availability is low in such soils. However, these $\mathrm{Ca}$ phosphates are easily dissolved when soils slightly acidify, leading to higher $\mathrm{P}$ availability. In non-calcareous soils with $\mathrm{pH}$ values below 5 , the solubility of $\mathrm{P}$ is known to be low since it is adsorbed to $\mathrm{Fe}$ and aluminium (Al) oxides (Blume et al. 2016; Jönsson Belyazid and Belyazid 2012).

Even though we did not find the expected relationship between foliar P contents and soil $\mathrm{pH}$ values, foliar $\mathrm{P}$ contents differed among soil acidification types and soil substrate groups in the expected way (Fig. 9.8). National Forest Soil Inventory II plots on soils with very high base saturation $(>85 \%)$ in the mineral top- and subsoil showed the lowest foliar P contents. In contrast, European beech trees on plots with slightly reduced base saturation (50-85\%) in the mineral topsoil showed the highest foliar P contents. Foliar P contents of European beech trees on soils with low base saturation have been in between these two groups. The group of NFSI plots with very high base saturation contains the plots in the calcareous Alps and plots on other pure calcareous soils. Indeed, on alpine soils, foliar P contents were lowest compared to all other soil parent material groups. In the calcareous Alps, P causes low vitality of European beech (Ewald 2000) and appears to be the most important nutrient limiting growth of Norway spruce (Mellert and Ewald 2014). The group of plots with slightly reduced base saturation in the mineral topsoil and highest foliar $\mathrm{P}$ contents contained shallowly acidified calcareous sites.

The foliar $\mathrm{P}$ content was weakly related to the $\mathrm{N}: \mathrm{P}$ ratio of the forest floor and mineral soil: the larger the N:P ratio, the smaller the foliar P content (Fig. 9.9). The $\mathrm{N}: \mathrm{P}$ ratio of the forest floor is influenced by site variables such as tree species composition and climate but also by $\mathrm{N}$ deposition. This would lead to the 


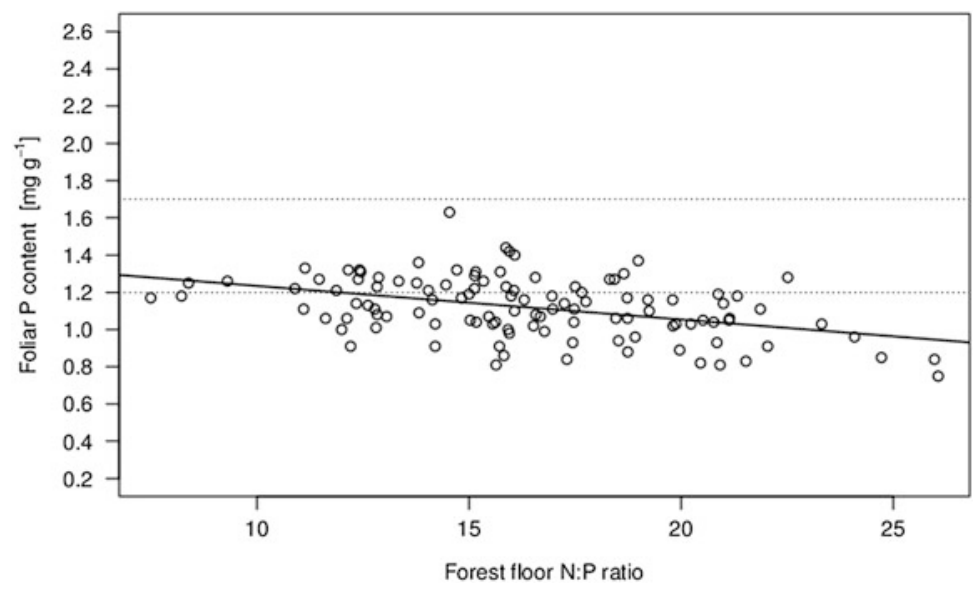

Fig. 9.9 Relationship between foliar $\mathrm{P}$ content and the N:P ratio in the forest floor $(\mathrm{L}+\mathrm{Of}+\mathrm{Oh})$ at European beech plots $\left(R^{2}=0.18, p<0.001\right)$; horizontal dashed lines mark the normal range for $\mathrm{P}$ according to Göttlein (2015), i.e. values below the lower line indicate latent P deficiency

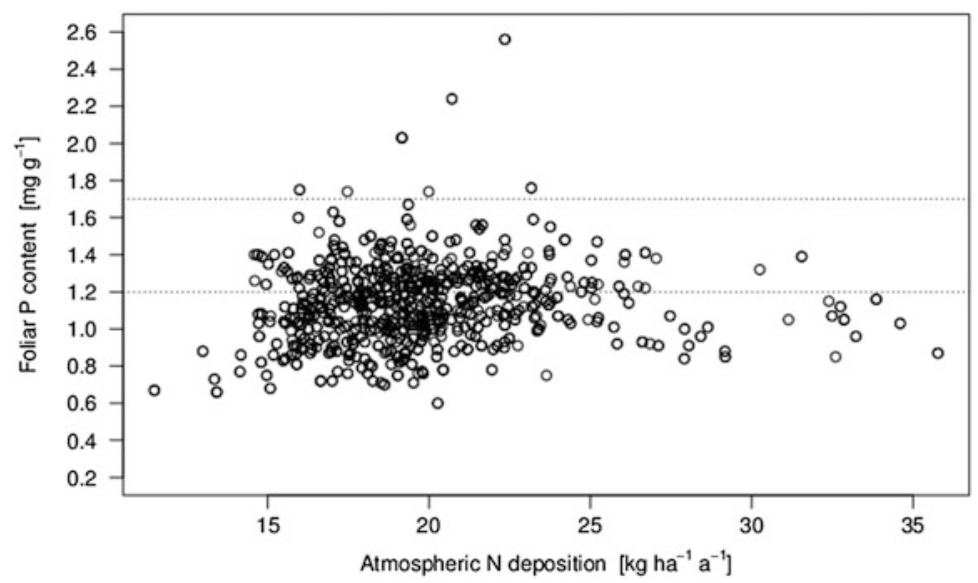

Fig. 9.10 Foliar $\mathrm{P}$ content versus total atmospheric $\mathrm{N}$ deposition at European beech plots; horizontal dashed lines mark the normal range for $\mathrm{P}$ according to Göttlein (2015), i.e. values below the lower line indicate latent P deficiency

expectation that foliar $\mathrm{P}$ contents are negatively related to $\mathrm{N}$ deposition (Braun et al. 2010). However, this could not be verified by the NFSI II dataset (Fig. 9.10).

The proportion of the variance in foliar $\mathrm{P}$ contents that was explained by the N:P ratio of all forest floor layers and mineral soil depths, i.e. the coefficient of determination, was much smaller than that found in the evaluation of the ICP Forests dataset, which contains time series of monitoring data (Talkner et al. 2015). The lower coefficient of determination may be due to the fact that foliar nutrients comprise 
high interannual variances, primarily due to meteorological differences among years (Evers 1972). Therefore, it is recommended to sample leaves in several (subsequent) years in order to be able to evaluate foliar nutritional status at a given site (Wehrmann 1959). Unfortunately, such a high sampling effort could not be realized in the NFSI. Hence, the data may represent the mean nutritional status throughout Germany and may even show coarse regional differences; however, the data may not be suitable for identifying correlations between foliar nutritional status and soil chemical parameters. This assumption is confirmed by the fact that all significant relationships between foliar $\mathrm{P}$ and soil chemical parameters found in the ICP Forests dataset when mean foliar P contents of several years were selected (Talkner et al. 2015) are no longer detectable when foliar ICP Forests data from just a single year were selected (data not published). In the latter case, close to the same coefficients of determination were found as with the NFSI II data set, which also comprised data from just 1 sampling year.

Since the determination of foliar $\mathrm{P}$ contents in several years is time- and resourceintensive, an indicator for foliar P status is urgently needed. Several soil extraction methods have been tested to assess the $P$ status of a site (Kohlpaintner et al. 2017). For European beech, the best relationship was found between foliar $\mathrm{P}$ and citrateextractable $\mathrm{P}$ in $0-10 \mathrm{~cm}$ soil depth. In addition, the $\mathrm{P}$ content of the forest floor seemed to be a rather good indicator, since, by litterfall, it directly represents the foliar P status of European beech (Talkner et al. 2015). Indeed, a significant positive relationship between foliar P content and the P content of the forest floor was found for European beech plots in the NFSI II (Fig. 9.11). However, the relationship was much weaker for the NFSI II compared to the ICP Forests dataset (Talkner et al. 2015), probably due to the constraints of the NFSI foliar data mentioned above.

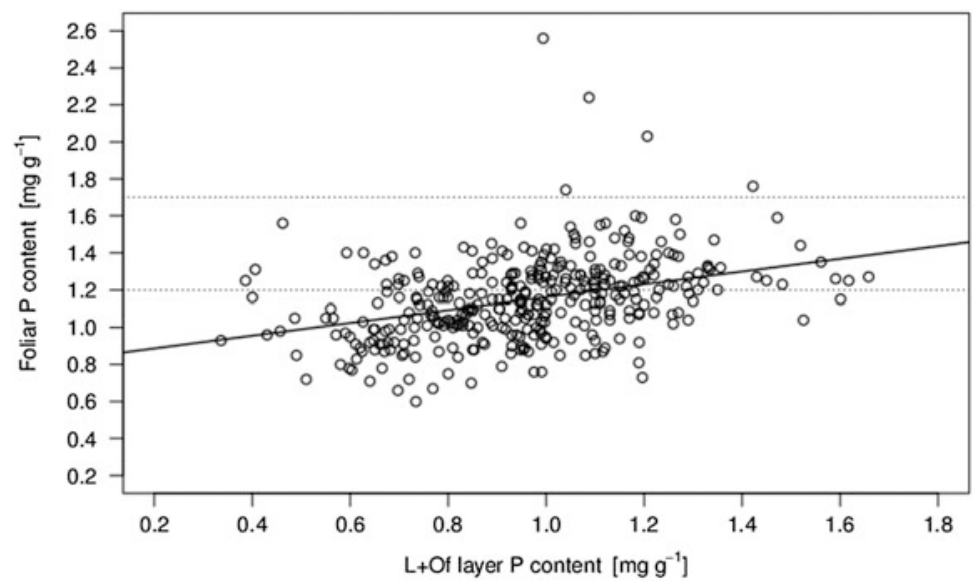

Fig. 9.11 Relationship between foliar $\mathrm{P}$ content and the $\mathrm{P}$ content in the $\mathrm{L}+\mathrm{O}$ layer of the forest floor at European beech plots $\left(R^{2}=0.16, p<0.001\right)$; horizontal dashed lines mark the normal range for $\mathrm{P}$ according to Göttlein (2015), i.e. values below the lower line indicate latent $\mathrm{P}$ deficiency 
Proper separation of the forest floor and the mineral soil is very important when evaluating P. Therefore, only the L or the L + Of layer should be considered.

In summary, the foliar P nutrition of European beech was deficient across large areas of Germany and deteriorated over time in some regions. Foliar P contents seem to be lowest on calcareous soils that are high in base saturation, indicating that the geological substrate (Augusto et al. 2017) may have influenced foliar P nutrition. The influence of atmospheric $\mathrm{N}$ deposition on $\mathrm{P}$ nutrition (Braun et al. 2010) can only be proven indirectly by the relationship between foliar $\mathrm{P}$ content and N:P ratio of the soil. Foliar nutritional data should be determined over several years in order to be able to evaluate the foliar $\mathrm{P}$ status of a given site. In addition to the search for single soil extraction methods that are able to adequately quantify plant-available $\mathrm{P}$ in soils, effort is required to determine if the $\mathrm{P}$ content of the forest floor would be a suitable indicator of the foliar P status of European beech forest sites.

\subsection{Foliar Sulphur Nutrition}

Sulphur dioxide is produced mainly during the combustion of fuels containing S. Since 1990, emissions have been reduced by $92 \%$, with the largest reductions occurring between 1990 and 1998 (UBA 2015), and according to this, also the S input to forest ecosystems decreased (Fig. 9.12 upper graphs). This was primarily due to the closure of power plants and other industrial plants in the former German Democratic Republic (GDR) and the implementation of exhaust gas cleaning technologies. Also the use of fuel with low or no $\mathrm{S}$ content had a decisive impact.

In 1987, when sampling for NFSI I began, $\mathrm{SO}_{2}$ emissions were high, showing a heavily polluted area in the southern part of the former GDR (Fig. 9.12, upper left). Corresponding to this, excessive foliar S nutrition was observed in eastern Germany (Fig. 9.12, lower left). In the other parts of Germany, foliar S nutrition was mostly within normal range. In the southern part of Bavaria, however, at the edge of the Alps, S deficiency was detected at many NFSI plots. Twenty years later, atmospheric $\mathrm{SO}_{2}$ concentrations were very low throughout Germany (Fig. 9.12, upper right), and only some single NFSI plots still had an excessive foliar S nutrition (Fig. 9.12, lower right). In contrast to NFSI I, many plots showed latent or clear deficiency, even in the eastern part of Germany. Regions with widespread S deficiency were again southern Bavaria with the Alps and additionally many regions with granitic bedrock, such as the Black Forest (in the southwest), the Bavarian Forest and the Ore Mountains (in the east at the border to the Czech Republic) and the Harz Mountains (in central Germany). Thus, forests experienced a dramatic change in $\mathrm{S}$ availability, from high and even too high concentrations in the atmosphere, leading to an above ground uptake path, to low concentrations in the atmosphere, causing sole availability of $\mathrm{S}$ from the soil. 

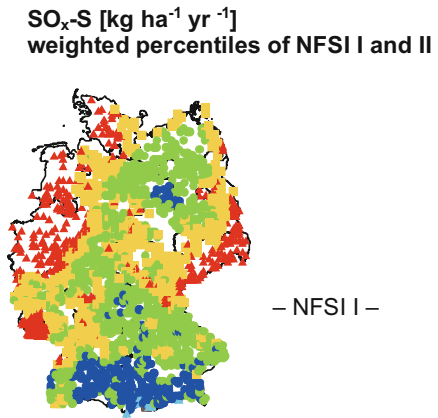

Sulfur nutritional status at NSFI (Göttlein 2015)
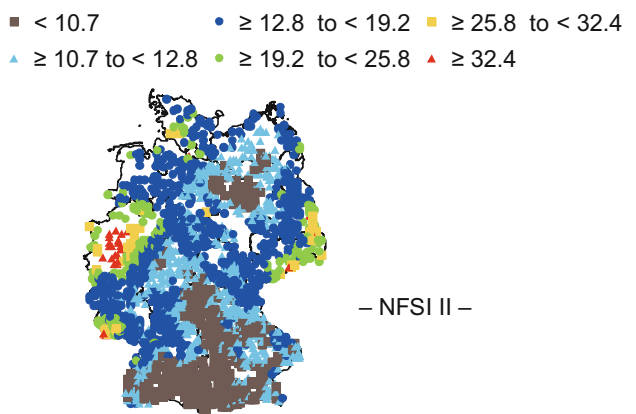

Nutritional ranges

- deficiency - latent deficiency " normal \& surplus
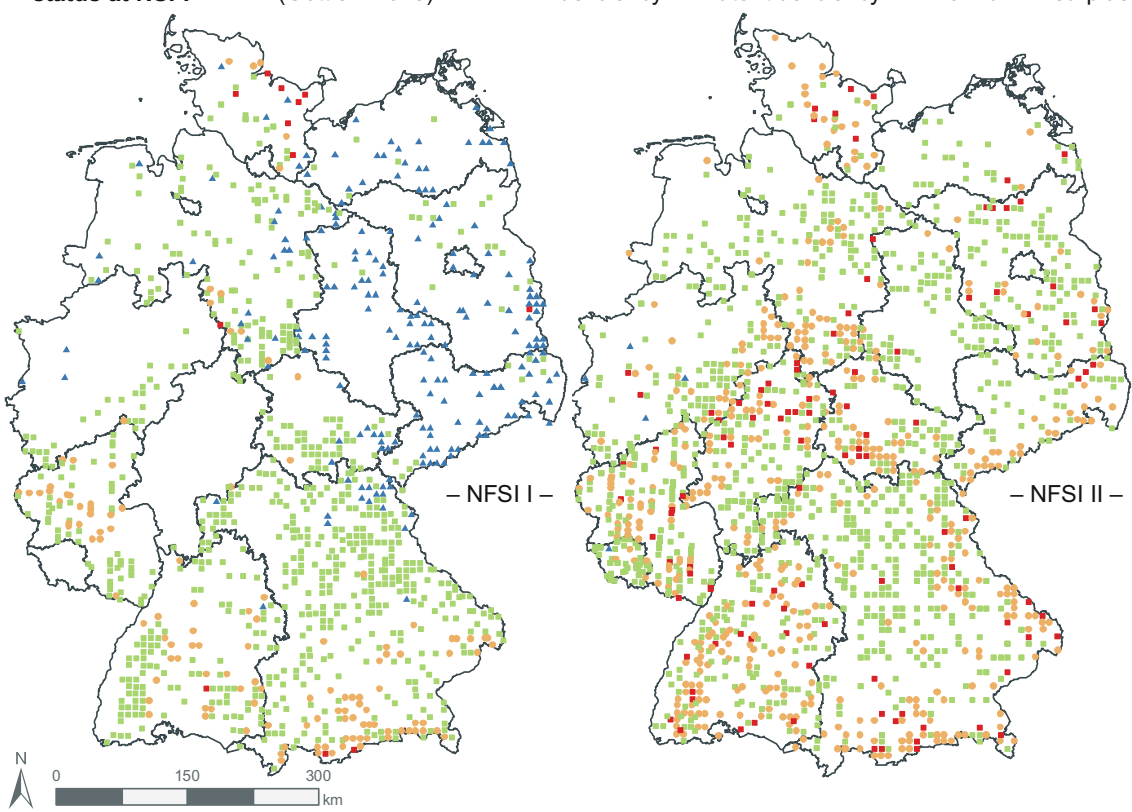

Fig. 9.12 Comparison of foliar S content for NFSI I and NFSI II; nutritional ranges are according to Göttlein (2015); the upper two graphs show the development of total S deposition from NFSI I to NFSI II

In the 1970s/1980s, sulphate accumulated in the mineral soil, depending on the atmospheric $S$ input and sulphate retention capacity of soils (Meiwes et al. 1980). Sulphur that accumulated in soils in times of high $\mathrm{S}$ emissions has been slowly released after the reduction of $S$ input (Alewell 2001). In 2007/2008, foliar $S$ contents were still dependent on water-extractable sulphate in the deeper mineral soil, while water-extractable sulphate in the upper soil layers had no effect on foliar $\mathrm{S}$ (Fig. 9.13). This means that the foliar S content is still influenced by inorganic sulphate retained in the subsoil, although atmospheric $\mathrm{S}$ input has decreased to about 
Fig. 9.13 Waterextractable sulphate (1:2 extract) of the nutritional ranges in different soil depths; average \pm standard error; different letters differ significantly with $p<0.05$; because data for waterextractable sulphate were available only in some federal states, this graph represents only a subset of NFSI II

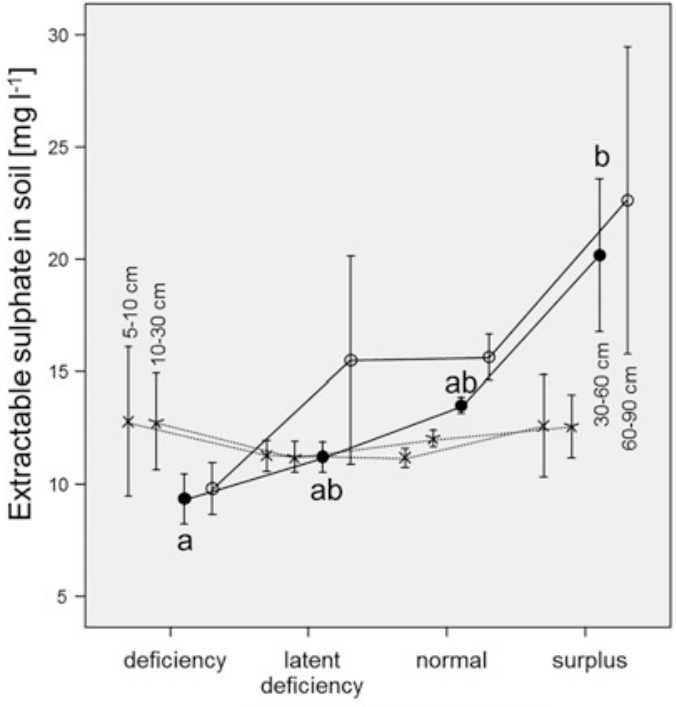

Nutritional range for $\mathrm{S}$

$10 \%$ compared to 1980 . Under these conditions, forests growing on parent material low in $\mathrm{S}$ in particular appear to run to $\mathrm{S}$ deficiency according to the expert-based thresholds for $S$ of Göttlein (2015) (Table 9.1). The nearly constant sulphate concentrations in the topsoil, independent from the nutritional status (Fig. 9.13), indicate that regulation processes of the ecosystem lead to a minimal amount of $\mathrm{S}$ cycling in the system.

Looking at the $\mathrm{S}$ content of the parent material (Table 9.4), acidic magmatic rocks, metamorphic rocks (with the exception of rich paragneiss) and sandstones have a very low $\mathrm{S}$ content. Although the geological parent material is often covered

Table 9.4 Sulphur content of various types of bedrock according to analyses by Ricke (1960), also including some other citations given by this author; values given as 5th-percentile, median and 95th-percentile

\begin{tabular}{|c|c|c|c|}
\hline Type & Bedrock & $n$ & $\begin{array}{l}\text { S [\%] } 5 \text { th perc. }- \text { median- } \\
\text { 95th perc. }\end{array}$ \\
\hline \multirow[t]{3}{*}{ Magmatic rock } & Acid (e.g. granite) & 31 & $0.006-\mathbf{0 . 0 1 4}-0.047$ \\
\hline & Intermediate (e.g. diorite) & 17 & $0.009-\mathbf{0 . 0 3 0}-0.199$ \\
\hline & Basic (e.g. basalt) & 18 & $0.013-\mathbf{0 . 0 3 3}-0.138$ \\
\hline \multirow[t]{2}{*}{$\begin{array}{l}\text { Metamorphic } \\
\text { rock }\end{array}$} & $\begin{array}{l}\text { Orthogneiss, quartzite, mica schist, } \\
\text { etc. }\end{array}$ & 6 & $0.013-\mathbf{0 . 0 1 9}-0.068$ \\
\hline & Paragneiss & 1 & 0.203 \\
\hline \multirow{4}{*}{$\begin{array}{l}\text { Sedimentary } \\
\text { rock }\end{array}$} & Sandstones & 9 & $0.006-\mathbf{0 . 0 2 3}-0.036$ \\
\hline & Greywacke & 6 & $0.128-\mathbf{0 . 1 5 4}-0.238$ \\
\hline & Clay, shale & 21 & $0.014-\mathbf{0 . 1 5 5}-0.500$ \\
\hline & Limestone, dolomite & 16 & $0.012-\mathbf{0 . 0 8 1}-0.211$ \\
\hline
\end{tabular}


Table 9.5 Threshold values for the range of normal S nutrition according to Göttlein et al. (2011); the age-separated values for European beech were calculated from the data set used in this publication

\begin{tabular}{|c|c|c|c|}
\hline \multicolumn{4}{|c|}{ Range of normal foliar S nutrition $\left[\mathrm{mg} \mathrm{g}^{-1}\right]$} \\
\hline Type & Norway spruce & Scots pine & European beech \\
\hline Young & $0.9-1.6$ & $1.0-1.4$ & $1.2-2.7$ \\
\hline Old & $0.8-1.4$ & $1.0-1.6$ & $1.2-3.0$ \\
\hline
\end{tabular}

by aeolic (loess) or other layers, regions with bedrock poor in $\mathrm{S}$ correspond well with regions with insufficient $S$ nutrition in NFSI II (Fig. 9.12).

Sulphur nutrition deteriorated from NFSI I to NFSI II (Fig. 9.12). This finding is supported by results from the ICP Forests Level II network (Jonard et al. 2015). The authors from that study found indications that mineral nutrition of trees progressively deteriorated in Europe with respect to $\mathrm{P}, \mathrm{S}$ and base cation nutrition. However, it has been questioned whether the threshold values used were reasonable, indicating that a large number of NFSI II plots were within the range of latent or clear S deficiency. Particularly, this question arises because many threshold values were established in times of high $\mathrm{S}$ emissions when a real $\mathrm{S}$ deficiency hardly occurred. In the extensive collection of nutritional data of van den Burg $(1985,1990)$, it is possible to distinguish between young and old European beech, Norway spruce and Scots pine trees. Young and old trees are not separated by a given age but by how the respective nutritional values were elaborated. Pot trials, experiments with nutrient solutions or studies using sand cultures can be done only using small (young) plants. Such experiments can be run under well-controlled conditions and thus should not be influenced by the $\mathrm{SO}_{2}$ emission regime. As shown in Table 9.5, the lower threshold values for normal $\mathrm{S}$ nutrition derived for young trees, under wellcontrolled conditions, and for old trees, under less-controlled conditions, are very close. This indicates that the previous higher $\mathrm{SO}_{2}$ emission had little impact on the threshold for S deficiency. Thus, the results of NFSI II must be interpreted in a way that on parent materials poor in $\mathrm{S}$, forests tend towards $\mathrm{S}$ shortage, which might induce a growth limitation in the long term. Sulphur is an element that should be increasingly considered for forestry practices that aim to be sustainable in terms of nutrients.

\subsection{Effects of Liming}

Forest ecosystems have been exposed to elevated atmospheric deposition of $\mathrm{S}$ and $\mathrm{N}$ for several decades (Waldner et al. 2014). Deposition of these compounds can contribute to acidification, fertilization and eutrophication (Ulrich 1981; Aber et al. 1989; Galloway et al. 2003), especially in nutrient-poor forest soils. Until the 1990s, $\mathrm{S}$ deposition has been the main factor causing soil acidification. With the strong reduction of $\mathrm{S}$ emissions, the relative contribution of $\mathrm{N}$ to soil acidification became more important (Schöpp et al. 2003; Meesenburg et al. 2016). Among other 
consequences, soil acidification causes the decline of soil cation exchange capacity and the loss of nutrient cations (de Vries et al. 2014). To mitigate the negative consequences of acidification, liming proved to be useful in improving soil chemical properties, foliar nutrition and tree vitality (Jonard et al. 2010). The aim of liming in German forests is to compensate for anthropogenic acidifying deposition and hence to ensure good nutritional status of trees (LAF 2000; von Wilpert et al. 2013). The decision criteria for liming include the impact of acidifying deposition, soil cation exchange characteristics of soils and foliar nutrition. Although atmospheric input of acids is decreasing, the critical loads of acidity are still exceeded in parts of Germany and Europe (Nagel et al. 2014; Waldner et al. 2014, 2015; Meesenburg et al. 2016). In addition, the prediction of time scales of reversibility of acidification is dependent on soil properties (Prechtel et al. 2001) and the development of deposition rates; a minimum of a few decades would be expected (Meesenburg et al. 2016). Therefore leaching of cationic nutrients with seepage water is an ongoing process, and forest liming will remain a common practice in some federal states of Germany. During the period from 1980 to 2012, approximately 3.2 million hectares of forest area were limed in Germany, in some cases twice (Jacob and Andreae 2012). Usually, dolomitic limestone containing $\mathrm{Mg}$ was applied. In some regions $\mathrm{P}$ was added.

To assess the effect of liming on foliar nutrition of the major tree species in Germany, we compared limed and unlimed NFSI II plots of those German states that limed on a large scale until the NFSI II (Rhineland-Palatinate, Lower Saxony, North Rhine-Westphalia, Baden-Wurttemberg, Hesse, Saxony, Thuringia). The selection of NFSI II plots that are considered to be sensitive to soil acidification was done according to the liming concepts of the respective federal states. The group of unlimed plots comprised only NFSI II plots that are sensitive to soil acidification but which have not yet been limed.

The foliar $\mathrm{N}$ content of the four major tree species did not differ on limed and unlimed NFSI II plots (Figs. 9.14, 9.15, 9.16, and 9.17). This result is in accordance with studies by Huber et al. (2006), Kulhavý et al. (2009), Jonard et al. (2010) and Greve et al. (2016), who determined no or slight liming effects in the foliar N content. The most likely explanation is the current high $\mathrm{N}$ deposition rates in Germany.

For Norway spruce, the foliar P content was slightly lower on limed NFSI II plots than on unlimed plots. The N:P ratio was not affected. However, the P status in the foliage of the other tree species showed no treatment effect. This result was unexpected, as in some regions, liming was combined with $\mathrm{P}$ fertilization. However, the applied $\mathrm{P}$ dosages stayed mostly undocumented, so their influence on foliar $\mathrm{P}$ content at NFSI II plots cannot be estimated. Results of other studies (von Wilpert 2003; Guckland et al. 2011) have found no reaction of the foliar P content after liming. However, Kulhavý et al. (2009) detected an increase of P in current-year needles of Norway spruce after liming, and Huber et al. (2006) reported on lower P contents in 1- and 2-year-old needles of Norway spruce 20 years after liming.

The foliar Ca content of European beech and oak was higher on limed than on unlimed plots. However, the $\mathrm{Ca}$ content for both tree species was mainly within normal range for both limed and unlimed plots. For Norway spruce and Scots pine, no liming effect on foliar Ca contents was observed. This does not correspond with results of field experiments. An increase in foliar Ca content after liming is known 

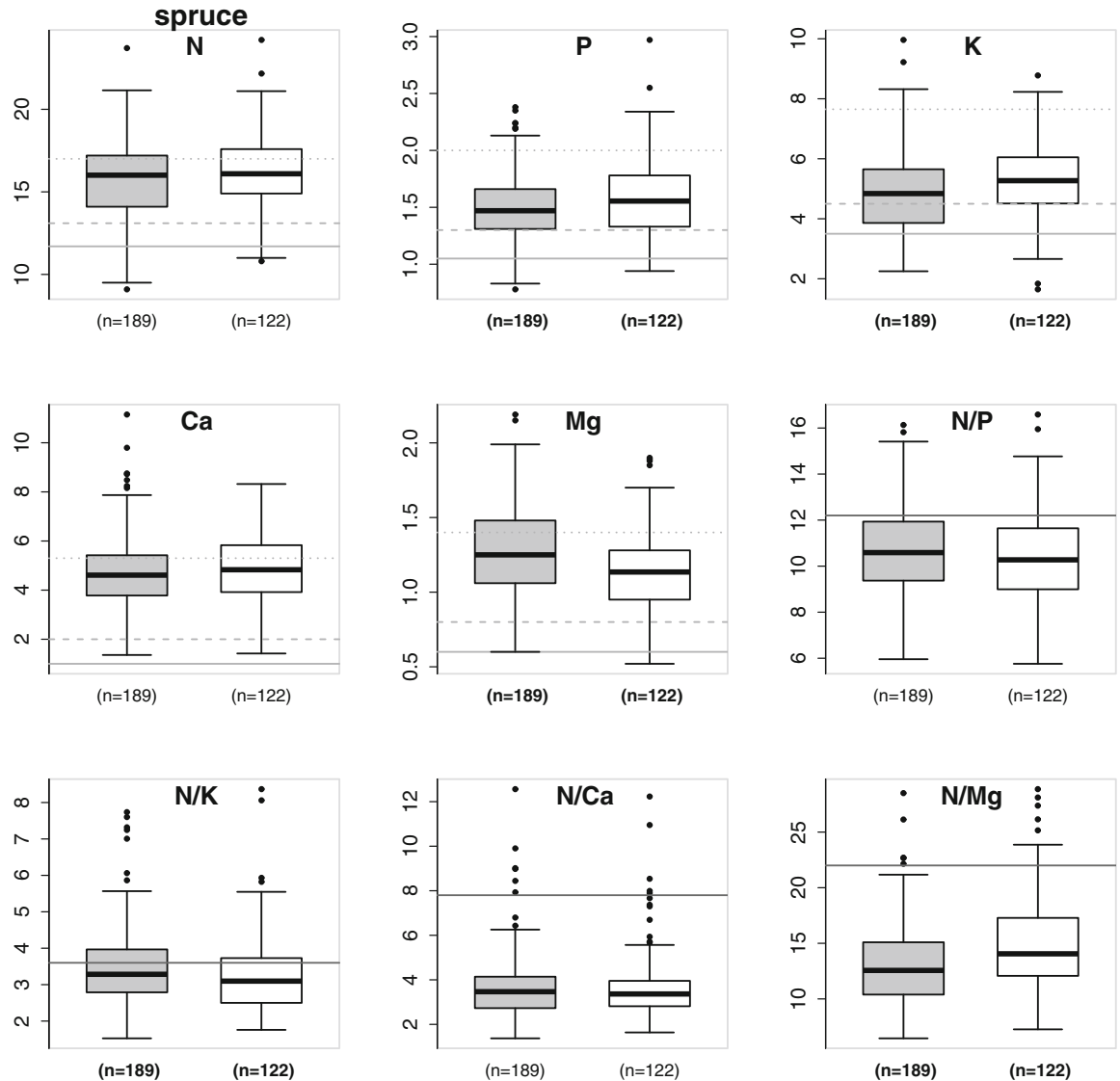

Fig. 9.14 Foliar $\mathrm{N}, \mathrm{P}, \mathrm{K}, \mathrm{Ca}$ and $\mathrm{Mg}$ contents $\left(\mathrm{mg} \mathrm{g}^{-1}\right)$ and ratios in current-year needles on limed (grey box) and unlimed (white box) NFSI II plots for Norway spruce. . ... upper threshold of normal range, --- lower threshold of normal range, _threshold of symptom range (Göttlein 2015) and critical $\mathrm{N}$ ratio, respectively (Table 9.3). In brackets, number of NFSI II plots; bold, significant difference $(p<0.05)$

from field experiments that compared limed and unlimed study plots under comparable site conditions (von Wilpert 2003; Kulhavý et al. 2009; Guckland et al. 2011; Greve 2014; Jonard et al. 2010). This discrepancy may be due to preferential liming of the most acidic soils, while the acidity of the reference group of unlimed, but still acidified soils, may be less.

The foliar Mg contents of limed Norway spruce, Scots pine, European beech and oak plots were higher than those of unlimed plots. In addition, they were within the normal range on limed plots, while they were in the (latent) deficiency range at up to $45 \%$ of unlimed European beech plots. Furthermore, the N:Mg ratio was significantly smaller on limed than on unlimed plots. These positive effects of liming are consistent with results from field experiments (Evers et al. 2008; Kulhavý et al. 2009; Jonard et al. 2010). At the NFSI II plots, foliar Mg content of Norway spruce and European beech increased with the frequency of liming (not shown). A lime 

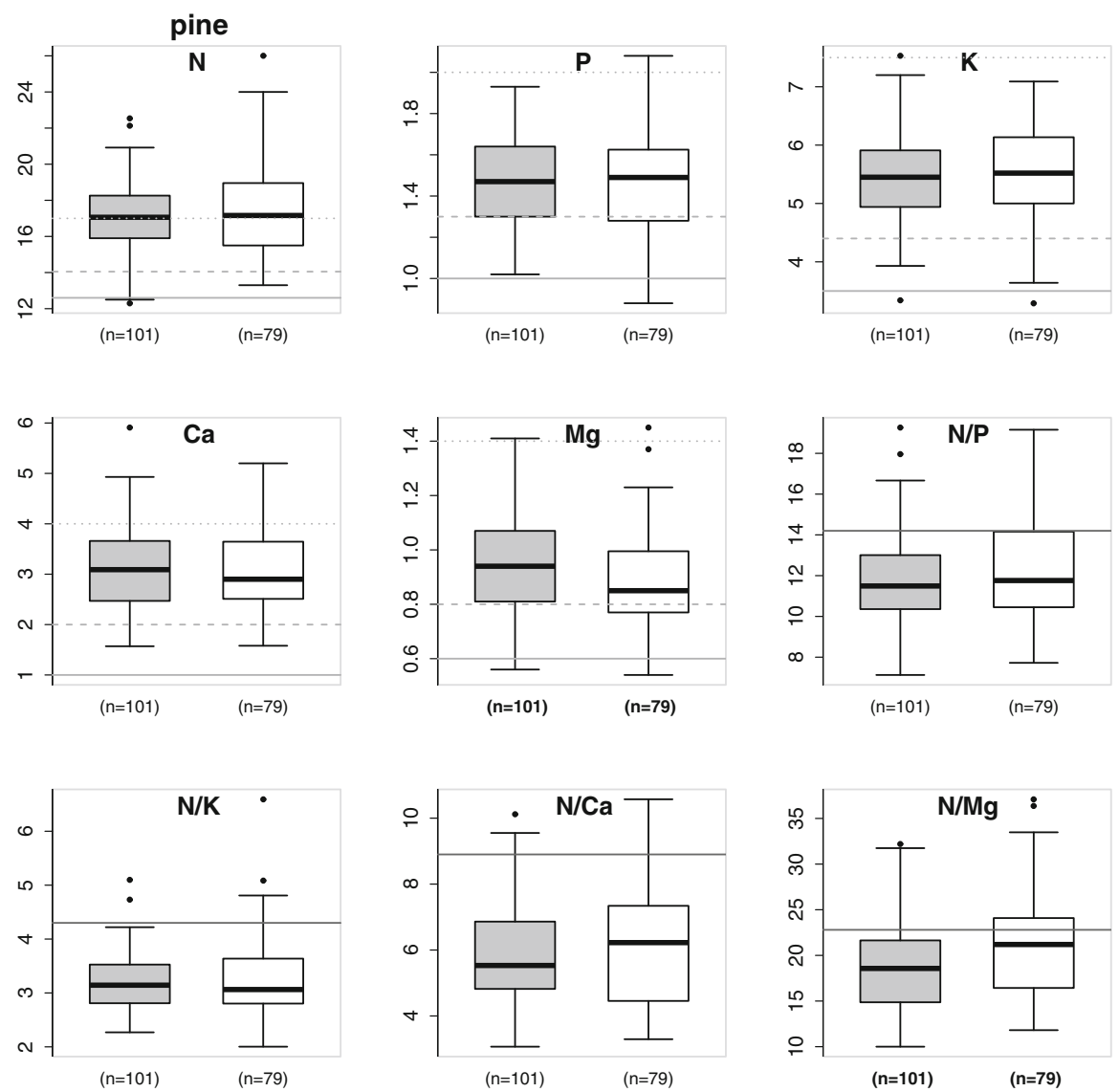

Fig. 9.15 Foliar $\mathrm{N}, \mathrm{P}, \mathrm{K}, \mathrm{Ca}$ and $\mathrm{Mg}$ contents $\left(\mathrm{mg} \mathrm{g}^{-1}\right)$ and ratios in current-year needles on limed (grey box) and unlimed (white box) NFSI II plots for Scots pine. .... upper threshold of normal range, --- lower threshold of normal range, _threshold of symptom range (Göttlein 2015) and critical $\mathrm{N}$ ratio, respectively (Table 9.3). In brackets, number of NFSI II plots; bold, significant difference $(p<0.05)$

dosage of $3 \mathrm{t} \mathrm{ha}^{-1}$ already improved the foliar $\mathrm{Mg}$ content; additional application provoked further significant increase.

In contrast to $\mathrm{Ca}$ and $\mathrm{Mg}$, foliar $\mathrm{K}$ contents of Norway spruce and European beech were lower on limed than on unlimed plots. There is inconsistent evidence regarding reduction of $\mathrm{K}$ in the foliage after liming in literature. In some studies, a decrease of $\mathrm{K}$ has been described (Evers et al. 2008; Weis et al. 2009; Ouimet et al. 2013; von Wilpert et al. 2013), whereas other studies have found no effect of liming (Huber et al. 2006; Kulhavý et al. 2009; Jonard et al. 2010). Guckland et al. (2011) assumed that the reduction of foliar K contents of Norway spruce and European beech is a matter of ion competition during nutrient uptake. Foliar $\mathrm{K}$ contents indicating (latent) deficiency were observed on about $40 \%$ and unbalanced $\mathrm{N}: \mathrm{K}$ ratios on $39 \%$ of limed Norway spruce and European beech NFSI II plots. For both tree 

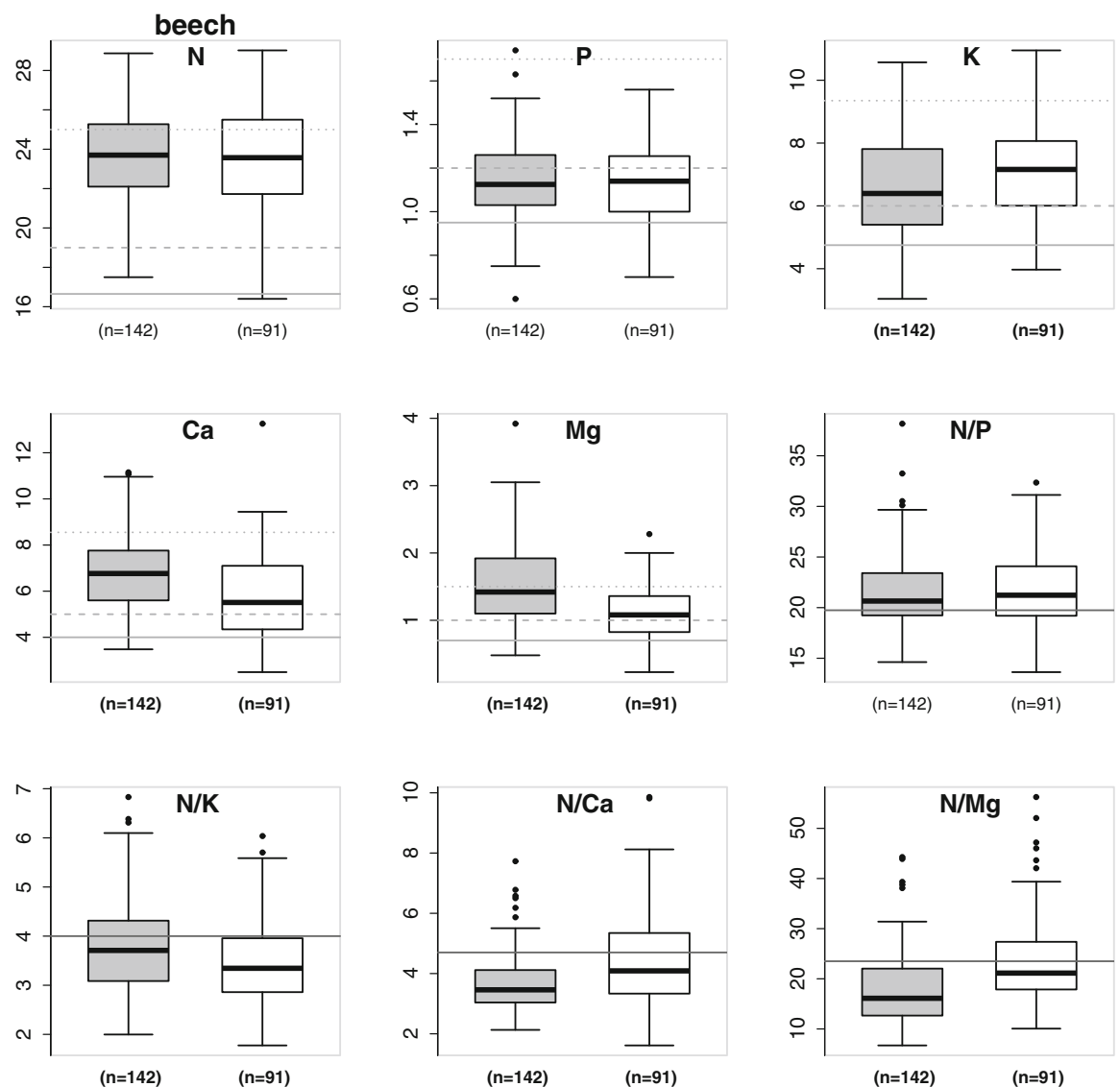

Fig. 9.16 Foliar $\mathrm{N}, \mathrm{P}, \mathrm{K}, \mathrm{Ca}$ and $\mathrm{Mg}$ contents $\left(\mathrm{mg} \mathrm{g}^{-1}\right)$ and ratios in current-year needles on limed (grey box) and unlimed (white box) NFSI II plots for European beech. .... upper threshold of normal range, --- lower threshold of normal range, _threshold of symptom range (Göttlein 2015) and critical $\mathrm{N}$ ratio, respectively (Table 9.3). In brackets, number of NFSI II plots; bold, significant difference $(p<0.05)$

species, the percentage of foliar K deficiency was about $25 \%$ on the unlimed NFSI II plots. On plots that were limed once with $3 \mathrm{t} \mathrm{ha}^{-1}$, foliar $\mathrm{K}$ contents were similar to those on unlimed plots, while on plots that were limed twice $\left(6 \mathrm{t} \mathrm{ha}^{-1}\right)$ or more, $\mathrm{K}$ contents were significantly lower than on unlimed plots. This indicates that after an application of at least $6 \mathrm{tha}^{-1}$ lime, a lowering effect on the foliar $\mathrm{K}$ content must be considered.

The findings at the NFSI II plots showed that liming of sites that are sensitive to soil acidification can contribute to sufficient and balanced foliar $\mathrm{Mg}$ content of Norway spruce, Scots pine, European beech as well as pedunculate and sessile oak. Regarding $\mathrm{Ca}$, the application of lime improved the nutrition of European beech and oak. However, a decrease of foliar K content of Norway spruce and 

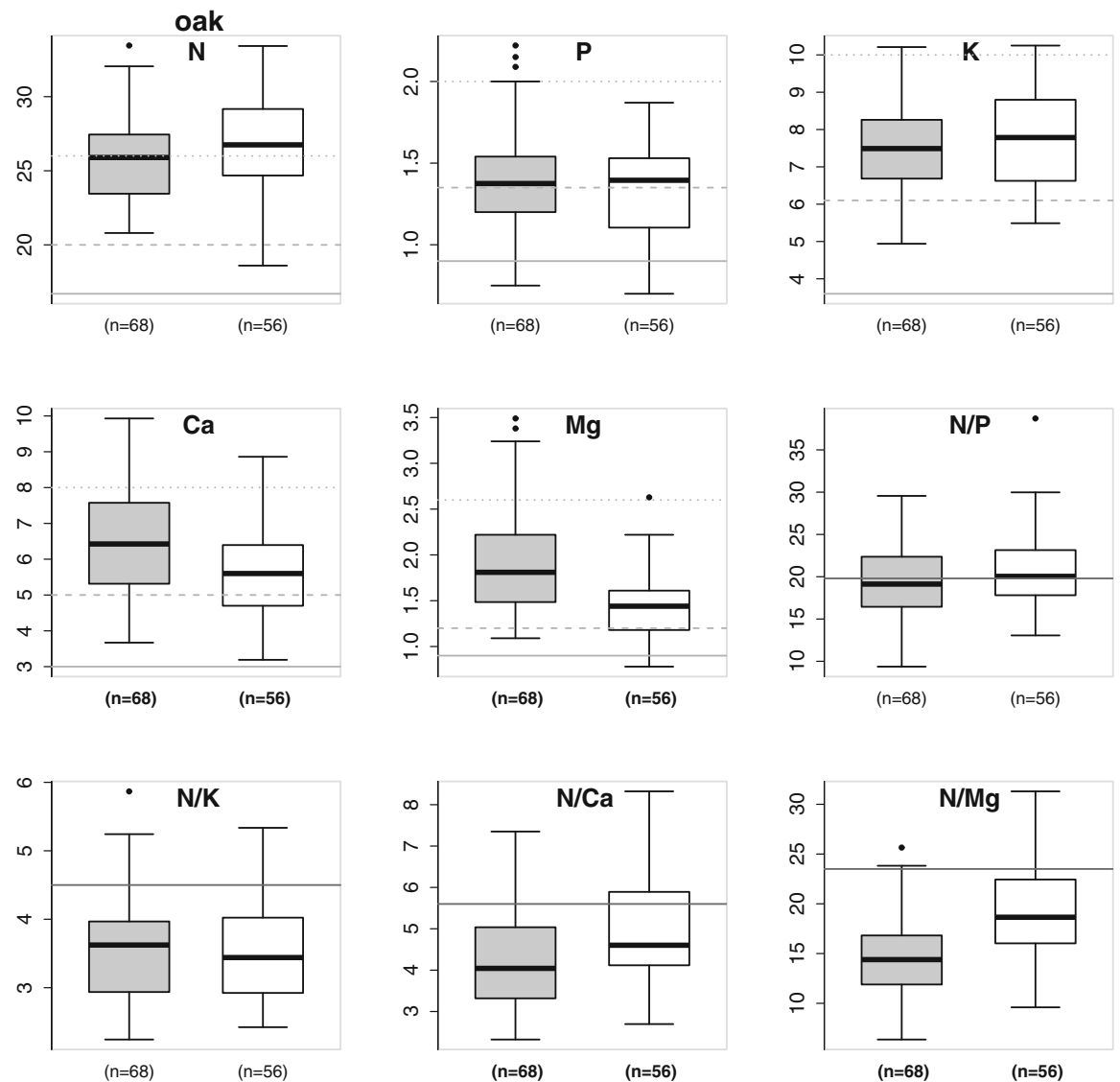

Fig. 9.17 Foliar $\mathrm{N}, \mathrm{P}, \mathrm{K}, \mathrm{Ca}$ and $\mathrm{Mg}$ contents $\left(\mathrm{mg} \mathrm{g}^{-1}\right)$ and ratios in current-year needles on limed (grey box) and unlimed (white box) NFSI II plots for pedunculate and sessile oak (pooled together). .... upper threshold of normal range, --- lower threshold of normal range, __ threshold of symptom range (Göttlein 2015) and critical $\mathrm{N}$ ratio, respectively (Table 9.3). In brackets, number of NFSI II plots; bold, significant difference $(p<0.05)$

European beech following lime dosages greater than $3 \mathrm{t} \mathrm{ha}^{-1}$ should be considered in the planning of liming.

\subsection{Effectiveness of Air Quality Control Measures with Respect to Lead}

It is well known that the canopy can act as a filter for air pollutants. For example, approximately $50-80 \%$ of the lead $(\mathrm{Pb})$ in needles of conifers may be adsorbed or taken up directly from the atmosphere (Shahid et al. 2017). This was demonstrated 
Table 9.6 Lead content in current-year needles of Norway spruce $(n=139)$ and Scots pine $(n=170)$ in NFSI I (1987-1992) and NFSI II (2007-2008)

\begin{tabular}{|c|c|c|c|c|}
\hline & \multicolumn{4}{|c|}{ Foliar $\mathrm{Pb}$ content $\left(\mathrm{mg} \mathrm{kg}^{-1} \mathrm{DW}\right)$} \\
\hline & \multicolumn{2}{|c|}{ Norway spruce } & \multicolumn{2}{|c|}{ Scots pine } \\
\hline & NFSI I & NFSI II & NFSI I & NFSI II \\
\hline Median & 1.00 & 0.34 & 2.80 & 0.45 \\
\hline Mean & 1.16 & 0.46 & 3.18 & 0.56 \\
\hline Std. dev. & 0.84 & 0.32 & 2.35 & 0.34 \\
\hline
\end{tabular}

by washing needles with water and analysing needles before and after washing (Al-Alawi and Mandiwana 2007), by removing and analysing the wax layer (Gandois and Probst 2012) or by analysing the dust particles separated from the wax (Staszewski et al. 2012). Klaminder et al. (2005) assessed foliar Pb uptake relating ${ }^{206} \mathrm{~Pb}:{ }^{207} \mathrm{~Pb}$ ratios in tree compartments to the corresponding isotopic ratios in different soil layers. Foliar $\mathrm{Pb}$ that is taken up directly from the atmosphere enters the leaf or needle mainly through stomata, cuticular cracks, lenticels, ectodesmata and aqueous pores (Shahid et al. 2017). Because of the Pb adsorption to the cuticle and the high rate of direct foliar $\mathrm{Pb}$ uptake, $\mathrm{Pb}$ content of unwashed foliage can be used as an indicator of $\mathrm{Pb}$ pollution in the atmosphere.

Mean $\mathrm{Pb}$ contents in unwashed current-year needles of Norway spruce (Picea abies) and Scots pine (Pinus sylvestris) decreased from NFSI I to NFSI II by $60 \%$ and $82 \%$, respectively (Table 9.6). This reflects the decreasing trend of $\mathrm{Pb}$ emissions in Germany, with a reduction from $2130 \mathrm{t} \mathrm{a}^{-1}$ in 1990 to $366 \mathrm{t} \mathrm{a}^{-1}$ in 2007 (UBA 2017). Lead in fuel for vehicles was the main $\mathrm{Pb}$ emission source. Since 1980, the use of unleaded fuel has increased, and since 2000, leaded fuel is no longer allowed within the European Union.

Mean $\mathrm{Pb}$ contents in current-year needles of Norway spruce and Scots pine measured on NFSI II plots are higher than $\mathrm{Pb}$ values measured in needles of lodgepole pine (Pinus contorta) and Sitka spruce (Picea sitchensis) in Western Ireland (0.15-0.17 mg Pb kg${ }^{-1} \mathrm{DW}$ ) (Asam et al. 2014) and in needles of silver fir (Abies alba) in the French Pyrenees (median $\pm \mathrm{SD}, 0.2 \pm 0.13 \mathrm{mg} \mathrm{Pb} \mathrm{kg}^{-1} \mathrm{DW}$ ) and Vosges Mountains (mean $\pm \mathrm{SD}, 0.33 \pm 0.11 \mathrm{mg} \mathrm{Pb} \mathrm{kg}^{-1} \mathrm{DW}$ ) (Gandois and Probst 2012; Gandois et al. 2010). Since the two investigated sites in Western Ireland are located about $30 \mathrm{~km}$ from the Atlantic coast, with prevailing west winds, the low $\mathrm{Pb}$ values in conifer needles may be considered as background values.

\subsection{Ratios of Nutrient Contents from Needles of Different Ages (Norway Spruce and Scots Pine)}

In addition to nutrient contents of current-year needles, element contents of 2- (Scots pine) and 3-year-old needles (Norway spruce) were analysed in the National Forest Soil Inventory II (NFSI II) in Germany. This analysis facilitates a more comprehensive diagnosis of the nutritional state of these two coniferous species. Furthermore, 
the analysis of element content in needles of different ages facilitates inferences about plant physiological processes, such as the translocation of nutrients from older to younger needles. For this purpose, the NFSI II is an outstanding database with 610 Scots pine and 409 Norway spruce sites. However, contents in needles of the NFSI dataset do not represent a real time series, as needles were sampled in the same year. Thus, it must be assumed that older needles had element contents in the year of formation that are comparable to contents of the current needle year. However, element contents in foliage can vary from year to year, especially during or after climatically extreme years (Göttlein et al. 2009; Jonard et al. 2009; Schleppi et al. 2000). This may be a problem for the evaluation of the dataset if there were a systematic deviation of element contents in the respective needle-formation year at all NFSI sites. However, this can be ruled out, since needle sampling was not simultaneous at all federal states but was spread over a 3-year period (2006-2008). Therefore, the mean values of the whole data set should allow the importance and tendencies of element ratios in Norway spruce and Scots pine needles of different ages to be assessed, assuming that changes in nutrient concentrations are not due to changes in the organic fraction of the needle (e.g. waxes, phenolics).

In adult trees, a large proportion of nutrients is stored in the foliar biomass (Beets and Pollock 1987; Fife et al. 2008; Alriksson and Eriksson 1998; ScarasciaMugnozza et al. 2000). Therefore, it stands to reason that this nutrient pool is used for internal reallocation processes. For example, Miller (1986) has shown that for the annual growth of 40-year-old European black pine, $40-50 \%$ of $\mathrm{N}$ and more than $50 \%$ of $\mathrm{P}$ were recruited by retranslocation processes running mainly within the foliar biomass. According to Miller (1986), retranslocation of nutrients might play an increasing role with advancing tree age and is particularly relevant in stands that have reached canopy closure and maximum crown sizes.

Retranslocation processes are more likely for nutrients deemed to be relatively mobile in plants such as N, P, K, Mg or S (Nambiar and Fife 1991). Especially in senescent needles, retranslocation of nutrients must be considered (Helmisaari 1992). However, nutrient retranslocation has been observed already in 6-monthold needles of several coniferous species (Fife et al. 2008).

There is no consistent pattern in literature regarding the question as to whether the nutritional state itself is controlling the extent of nutrient retranslocation. Miller et al. (1979) found increased N retranslocation within needles of European black pine in stands with poor $\mathrm{N}$ nutrition. At the same time, increased element retranslocation has been observed with increasing plant availability of the respective element. For instance, in an N-fertilized Pinus radiata stand, Fife and Nambiar (1997) detected a growth increase of $45 \%$ and simultaneously an $\mathrm{N}$ retranslocation that rose by a factor of 4.5 .

All of the studies mentioned above were case studies involving only one or a small number of sites. We tested the extent to which the findings of these studies of nutrient retranslocation in the foliar biomass are reflected by the extensive data set of the NFSI II using Norway spruce and Scots pine. We examined whether nutritional diagnosis can be improved for these two coniferous species by considering ratios 
between foliar element contents of current-year needles and of 2- (Scots pine) or 3(Norway spruce) year-old needles. In addition, we assigned these ratios to one of four nutritional ranges based on the assessment system of Göttlein (2015) in order to evaluate nutrient ratios (and potential retranslocation processes) dependent on the nutritional state of the respective element in the current-year needles.

As shown in Fig. 9.18, ratios of $\mathrm{N}$ contents differ for the two tree species. For Norway spruce, there is a slight decrease (10\%) in relative $\mathrm{N}$ contents in 3-year-old needles at sites with $\mathrm{N}$ deficiency. With improving $\mathrm{N}$ nutrition, the relative $\mathrm{N}$ contents in older needles decrease significantly, reaching $83 \%$ of the $\mathrm{N}$ contents in the current needle year at sites classified as $\mathrm{N}$ surplus sites. $\mathrm{N}$ is deemed to be a mobile nutrient in plants. Therefore, it is likely that the observed decrease in $\mathrm{N}$ contents in 3-year-old needles is caused by retranslocation processes. However, a weight increase among older needles may also contribute to the $\mathrm{N}$ content decrease in needles of this age. Consistent with the results of the study by Fife and Nambiar (1997), our findings suggest that the reduction of relative $\mathrm{N}$ contents in older needles with increasing $\mathrm{N}$ nutrition is likely caused by additional biomass growth. Thus, at many Norway spruce sites with normal or surplus $\mathrm{N}$ nutrition, $\mathrm{N}$ stimulates additional biomass growth. In contrast, this appears not to be the case for Scots pine. For this species, $\mathrm{N}$ contents of older needles are slightly higher or similar compared to contents of current-year needles, and there is no significant pattern between sites of different $\mathrm{N}$ nutritional states. The growth of Scots pine at sites with normal and surplus $\mathrm{N}$ nutrition seems to be limited by other factors. This is likely also true for Scots pine at $\mathrm{N}$-deficient sites, because otherwise a difference of $\mathrm{N}$ contents between younger and older needles would be expected, as reported in Miller et al. (1979).

The ratios of $\mathrm{P}$ show similar patterns for Norway spruce and Scots pine. With increasing $\mathrm{P}$ nutrition, relative $\mathrm{P}$ contents in older needles decrease significantly, reaching only $72 \%$ of current-year $\mathrm{P}$ content at sites with surplus $\mathrm{P}$ nutrition for Norway spruce and $87 \%$ for Scots pine, respectively. $\mathrm{P}$ is also considered a readily mobile nutrient. Thus, retranslocation of $\mathrm{P}$ from older to current-year needles is likely, even if - as mentioned above - a weight increase in older needles contributes to the decrease of $\mathrm{P}$ contents in needles of this age. For Norway spruce, lowered $\mathrm{P}$ contents in older needles were detected already at sites with P deficiency, whereas at Scots pine sites with P deficiency, $\mathrm{P}$ contents did not differ between current-year and 2 -year-old needles. This suggests that $P$ retranslocation between different aged Scots pine needles is less effective for Scots pine than Norway spruce. However, at $\mathrm{N}=7$, the sample size for this nutritional range is very low compared to the other ranges observed in this study.

Even for K, relative contents in the older needles of Norway spruce and Scots pine decrease significantly with increasing $\mathrm{K}$ nutrition range in current-year needles. For trees with surplus $\mathrm{K}$ nutrition, the relative $\mathrm{K}$ contents in older needles drop to less than $80 \%$ of contents measured in current-year needles. This was observed for both Norway spruce and Scots pine. Again, $\mathrm{K}$ is considered highly mobile in plants. Therefore, increasing retranslocation of $\mathrm{K}$ with rising $\mathrm{K}$ nutrition is highly likely and supports the hypothesis discussed in Nambiar and Fife (1991) that the extent of retranslocation of $\mathrm{K}, \mathrm{P}$ and $\mathrm{N}$ mostly shows a positive relationship to the absolute quantity of the respective element stored in the foliar biomass. However, a weight 

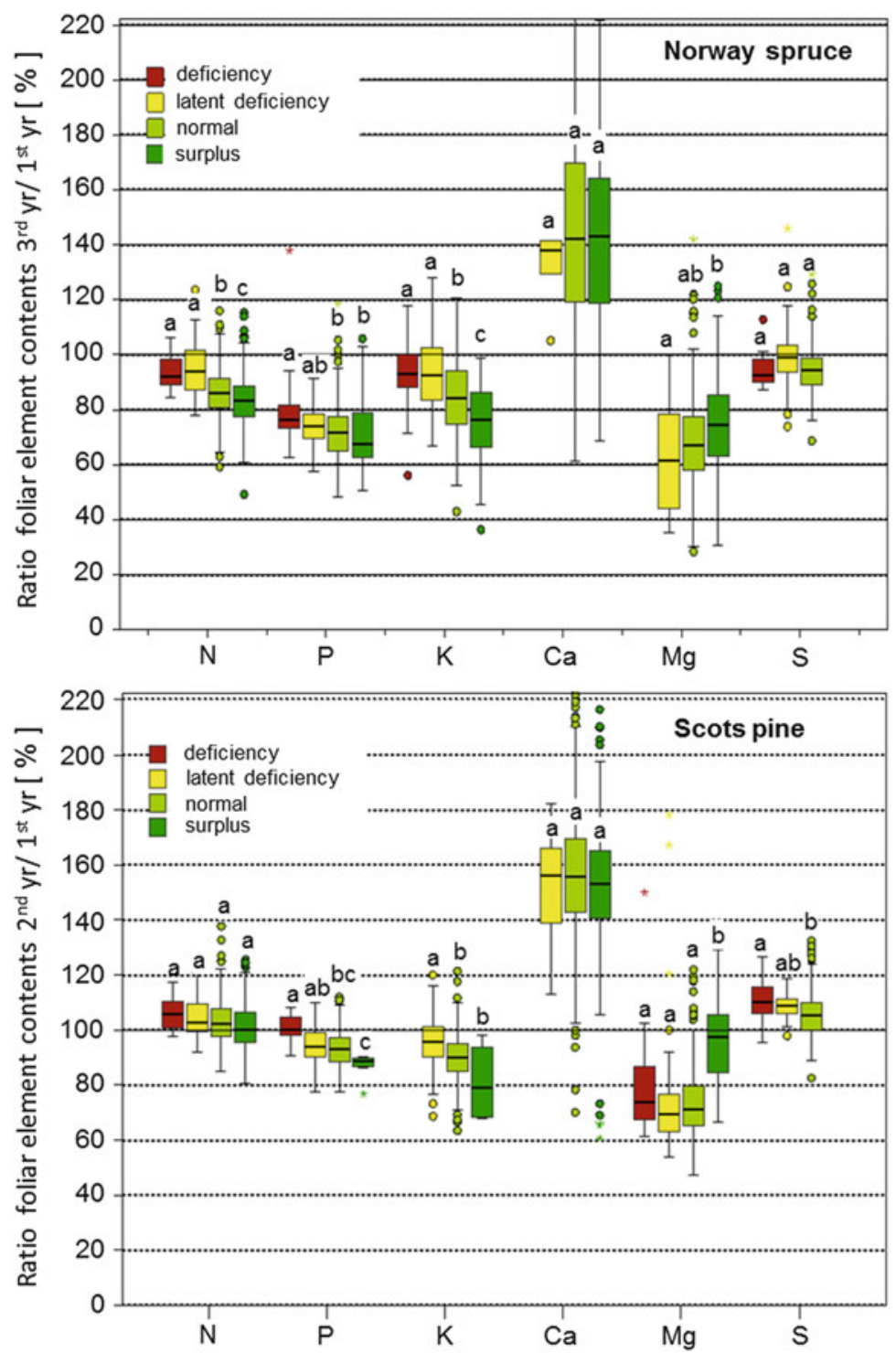

Fig. 9.18 Ratios between foliar element contents of 2- (Scots pine) or 3-year-old needles (Norway spruce) and current-year needles, grouped by nutritional ranges based on the assessment system of Göttlein (2015). Letters above boxplots indicate statistically significant differences between nutritional ranges of the respective element (Scheffé test, $\alpha<0.05$ )

increase among older needles may also contribute to the $\mathrm{K}$ content decrease in previous year needles.

For $\mathrm{Ca}$, distinctly higher contents in older needles were observed at Norway spruce sites $(+40 \%)$ as well as at Scots pine sites $(+55 \%)$. This relative increase of Ca 
contents in older needles was visible in all nutritional ranges; i.e. it is independent of $\mathrm{Ca}$ contents in current-year needles. This is highly plausible as $\mathrm{Ca}$ in plant tissues is largely organically bound and therefore not translocated through the phloem. Furthermore, $\mathrm{Ca}$ is constantly supplemented by transpiration flow (Kadereit et al. 2014), leading to an enrichment of $\mathrm{Ca}$ contents in older needles which has been already observed in previous studies for Norway spruce and Scots pine (e.g. Bauer et al. 2000). It is notable that Ca ratios show the greatest variability compared to the other main nutrients shown in Fig. 9.18. This is consistent with the results of previous case studies that have observed the highest annual fluctuation of Ca contents in needles of Norway spruce (Evers 1972) and Scots pine (Hippeli and Branse 1992) compared to other main nutrients. It is quite likely that this is also reflected in the large-scale data set of the NFSI II.

Compared to the other nutrients, $\mathrm{Mg}$ shows the greatest reduction in relative contents in older needles for both tree species (Fig. 9.18). This reduction is highest in trees with latent $\mathrm{Mg}$ deficiency, where contents in previous year needles drop to 60\% for Norway spruce and $70 \%$ for Scots pine. In contrast, relative $\mathrm{Mg}$ contents in older needles amount to $80 \%$ (Norway spruce) and nearly 100\% (Scots pine) for trees assigned to the surplus Mg nutrition range. These findings are consistent with the results of other studies, where an increase in $\mathrm{Mg}$ retranslocation has been detected when Mg nutrition declined (Le Goaster et al. 1990; Reemtsma 1986).

Although S appears to be organically bound in plants, in the literature it is considered a rather mobile nutrient (Nambiar and Fife 1991; Rennenberg 1999; Köstner et al. 1998). However, only very small or no S content gradients between current-year and older needles were detected for Norway spruce. In contrast, a slight enrichment of $S$ in older needles of Scots pine was observed in all nutritional ranges. While this enrichment decreases slightly with increasing $\mathrm{S}$ nutrition in current-year needles of Scots pine, we found no statistically significant differences between $S$ nutrition ranges for Norway spruce (Fig. 9.18). As $\mathrm{S}$ can also be taken up directly by the foliage, $\mathrm{S}$ enrichment in older needles cannot be excluded, although airborne deposition of $\mathrm{S}$ has reduced considerably in Germany in recent years.

In summary, the ratios of contents of the main nutrients between current-year and older needles at Norway spruce and Scots pine sites of the NFSI II provide a means for drawing plausible conclusions. For both tree species, the immobile element $\mathrm{Ca}$ shows an enrichment in older needles, whereas for nutrients considered relatively mobile in plants $(\mathrm{N}, \mathrm{P}, \mathrm{K}, \mathrm{Mg})$, retranslocation from older into current-year needles is likely. The extent of element translocation and enrichment, respectively, corresponds to the general nutritional state for these two tree species (Fig. 9.1). For Scots pine, a species with relatively low nutrient requirements, the NFSI data set reveals a generally better nutritional situation and at the same time a higher enrichment of the immobile Ca compared to Norway spruce. The retranslocation of mobile nutrients shows similar patterns for both species, but the extent of foliar element retranslocation appears to be lower in most cases for Scots pine.

Above, we discussed whether nutritional state itself controls the extent of nutrient retranslocation; even the large-scale dataset of the NFSI II cannot provide a clear answer. In the case of $\mathrm{Mg}$, retranslocation from older to current-year needles 
increases with declining $\mathrm{Mg}$ nutrition in current-year needles for both tree species. In contrast, our findings suggest that $\mathrm{P}$ and $\mathrm{K}$ are increasingly translocated with improving nutritional range of the respective element in current-year needles at Norway spruce and Scots pine sites. For N, this effect applies only to Norway spruce, whereas for Scots pine, no significant differences of $\mathrm{N}$ contents between current-year and older needles were observed over all $\mathrm{N}$ nutritional ranges, suggesting that at many Scots pine sites, growth seems to be limited by other factors.

Precise determination of foliar element translocation within needle years requires that the nutritional data should originate from real time series, and furthermore, the weight of foliar biomass should be assessed for each needle year in order to calculate retranslocation on the level of annual changes of element quantities. As these data are not available, we were not able to exclude the possibility that a weight increase among older needles contributed to foliar element content changes that are not related to retranslocation processes.

\subsection{Conclusions}

Nutrient contents in the leaves and needles of the four major tree species on NFSI plots provided valuable information about the current nutritional status in Germany and revealed effects of increased $\mathrm{N}$ deposition, forest soil liming and air quality control measures on nutritional status. The hypotheses tested were largely confirmed by the NFSI dataset:

1. Foliar $\mathrm{N}$ contents are related to atmospheric $\mathrm{N}$ deposition.

2. Foliar P contents of European beech are deficient through large areas of Germany. Both geological substrate and atmospheric $\mathrm{N}$ deposition may influence foliar $\mathrm{P}$ nutrition.

3. Foliar S contents are related to sulphate concentration in water extracts of subsoil samples. Due to a marked decrease in $\mathrm{S}$ deposition, stands at sites low in geogenic $\mathrm{S}$ tend to have an $\mathrm{S}$ shortage.

4. Liming of acidified soils leads to increased foliar $\mathrm{Ca}$ and $\mathrm{Mg}$ contents, while foliar $\mathrm{K}$ contents decrease.

5. Air quality control measures lead to decreased foliar lead contents.

6. The nutritional diagnosis for conifers can be improved by considering the ratios between foliar element contents of 2- (Scots pine) or 3- (Norway spruce) year-old needles and current-year needles.

We showed that foliar element contents are important for evaluating the current nutritional status of forest ecosystems and facilitate conclusions about the effectiveness of forest stabilization and air quality control measures.

However, field and laboratory experiments are needed to reveal the causes for decreasing foliar $\mathrm{P}$ and $\mathrm{K}$ contents. The presence of deficient foliar $\mathrm{P}, \mathrm{S}$ and $\mathrm{K}$ contents and high $\mathrm{N}$ to nutrient ratios indicates a critical nutrient status and should be considered in forest management planning, especially forest biomass harvesting. In 
general, foliar element contents should be included in decision support systems for sustainable forestry.

When working with NFSI data, it should always be considered that leaves and needles were collected in a single year only and that the sampling year varied among the federal states of Germany. Hence, annual fluctuations in foliar nutrient contents cannot be accounted for and may affect the differences in foliar nutritional status among NFSI plots and relationships to other parameters.

\section{References}

Aber JD, Nadelhoffer KJ, Steudler P, Melillo JM (1989) Nitrogen saturation in northern forest ecosystems. Bioscience 39(6):378-386

Aber JD, McDowell W, Nadelhoffer K, Magill A, Berntson G, Kamakea M, McNulty S, Currie W, Rustad L, Fernandez I (1998) Nitrogen saturation in temperate forest ecosystems - hypotheses revisited. Bioscience 48(11):921-934. https://doi.org/10.2307/1313296

Aber JD, Goodale CL, Ollinger SV, Smith M-L, Magill AH, Martin ME, Hallett RA, Stoddard JL (2003) Is nitrogen deposition altering the nitrogen status of northeastern forests? AIBS Bull 53 (4):375-389

Aerts R, Chapin FS (2000) The mineral nutrition of wild plants revisited: a re-evaluation of processes and patterns. Adv Ecol Res 30:1-67

Al-Alawi MM, Mandiwana KL (2007) The use of Aleppo pine needles as a bio-monitor of heavy metals in the atmosphere. J Hazard Mater 148(1-2):43-46. https://doi.org/10.1016/j.jhazmat. 2007.02.001

Alewell C (2001) Predicting reversibility of acidification: the European sulfur story. Water Air Soil Pollut 130(1-4):1271-1276. https://doi.org/10.1023/a:1013989419580

Alriksson A, Eriksson HM (1998) Variations in mineral nutrient and C distribution in the soil and vegetation compartments of five temperate tree species in NE Sweden. For Ecol Manag 108 (3):261-273. https://doi.org/10.1016/s0378-1127(98)00230-8

Asam Z, Nieminen M, Kaila A, Laiho R, Sarkkola S, O'Connor M, O'Driscoll C, Sana A, Rodgers M, Zhan XM, Xiao LW (2014) Nutrient and heavy metals in decaying harvest residue needles on drained blanket peat forests. Eur J For Res 133(6):969-982. https://doi.org/10.1007/ s10342-014-0815-5

Augusto L, Achat DL, Jonard M, Vidal D, Ringeval B (2017) Soil parent material—a major driver of plant nutrient limitations in terrestrial ecosystems. Glob Chang Biol 23(9):3808-3824. https://doi.org/10.1111/gcb.13691

Bauer G, Persson H, Persson T, Mund M, Hein M, Kummetz E, Matteucci G, Van Oene H, Scarascia-Mugnozza G, Schulze E-D (2000) Linking plant nutrition and ecosystem processes. In: Schulze ED (ed) Carbon and nitrogen cycling in European forest ecosystems. Springer, Berlin, pp 63-98

Beets P, Pollock D (1987) Accumulation and partitioning of dry matter in Pinus radiata as related to stand age and thinning. N Z J For Sci 17(2):246-271

Blume H-P, Brümmer GW, Fleige H, Horn R, Kögel-Knabner I, Kandeler E, Kretzschmar R, Stahr K, Wilke B-M (2016) Scheffer/Schachtschabel Soil Science. Springer, Berlin

Braun S, Thomas VF, Quiring R, Flückiger W (2010) Does nitrogen deposition increase forest production? The role of phosphorus. Environ Pollut 158(6):2043-2052

Burschel P, Huss J, Kalbhenn R (1964) Die natürliche Verjüngung der Buche: mit 63 Tabellen. Sauerländer

Cape JN, Freer-Smith PH, Paterson IS, Parkinson JA, Wolfenden J (1990) The nutritional status of Picea abies (L) Karst. across Europe, and implications for "forest decline". Trees 4(4):211-224 
de Vries W, Reinds GJ, Gundersen P, Sterba H (2006) The impact of nitrogen deposition on carbon sequestration in European forests and forest soils. Glob Chang Biol 12:1151-1173

de Vries W, Reinds GJ, van Kerkvoorde MS, Hendriks CMA, Leeters EEJM, Gross CP, Voogd JCH, Vel EM (2000) Intensive monitoring of forest ecosystems in Europe. EC, UN/ECE, Brussels, Geneva

de Vries W, Dobbertin MH, Solberg S, Van Dobben HF, Schaub M (2014) Impacts of acid deposition, ozone exposure and weather conditions on forest ecosystems in Europe: an overview. Plant Soil 380(1-2):1-45

Evers FH (1972) Die jahrweisen Fluktuationen der Nährelementkonzentrationen in Fichtennadeln und ihre Bedeutung für die Interpretation nadelanalytischer Befunde. Allgemeine Forst- und Jagdzeitung 143:68-74

Evers J, Dammann I, Noltensmeier A, Nagel R-V (2008) Auswirkungen von Bodenschutzkalkungen auf Buchenwälder (Fagus sylvatica L.). In: Ergebnisse angewandter Forschung zur Buche. Beiträge aus der NW-FVA, vol 3. Nordwestdeutsche Forstliche Versuchsanstalt (NW-FWA), Göttingen, pp 21-50

Ewald J (2000) Does phosphorus deficiency cause low vitality in European beech (Fagus sylvatica L.) in the Bavarian Alps? Forstwissenschaftliches Centralblatt 119(5):276-296

Ewald J (2005) Ecological background of crown condition, growth and nutritional status of Picea abies (L.) Karst. in the Bavarian Alps. Eur J For Res 124(1):9-18

Fiedler HJ, Höhne H (1984) Das NPK-Verhältnis in Kiefernnadeln als Erscheinung und Mittel zur Ernährungsdiagnose. Beitr Forstwirtsch 18:128-132

Fife DN, Nambiar EKS (1997) Changes in the canopy and growth of Pinus radiata in response to nitrogen supply. For Ecol Manag 93(1):137-152

Fife DN, Nambiar EKS, Saur E (2008) Retranslocation of foliar nutrients in evergreen tree species planted in a Mediterranean environment. Tree Physiol 28(2):187-196

Flückiger W, Braun S (1999) Nitrogen and its effect on growth, nutrient status and parasite attacks in beech and Norway spruce. Water Air Soil Pollut 116(1-2):99-110

Flückiger W, Braun S (2003) Critical limits for nutrient concentrations and ratios for forest trees-a comment. Empirical critical loads for nitrogen. Swiss Agency for the Environment, Forests and Landscape (SAEFL), Berne

Galloway JN, Aber JD, Erisman JW, Seitzinger SP, Howarth RW, Cowling EB, Cosby BJ (2003) The nitrogen cascade. AIBS Bull 53(4):341-356

Gandois L, Probst A (2012) Localisation and mobility of trace metal in silver fir needles. Chemosphere 87(2):204-210

Gandois L, Nicolas M, Vanderheijden G, Probst A (2010) The importance of biomass net uptake for a trace metal budget in a forest stand in north-eastern France. Sci Total Environ 408 (23):5870-5877

Gauger T, Haenel H-D, Rösemann C, Dämmgen U, Bleeker A, Erisman JW, Vermeulen AT, Schaap M, Timmermanns RMA, Builtjes PJH (2008) National implementation of the UNECE convention on long-range transboundary air pollution (effects). Part 1: Deposition loads: methods, modelling and mapping results, trends. UBA-Texte vol 08/38. Umweltbundesamt, Dessau-Roßlau

Glatzel G, Kazda M, Grill D, Halbwachs G, Katzensteiner K (1987) Ernährungsstörungen bei Fichte als Komplexwirkung von Nadelschäden und erhöhter Stickstoffdeposition - ein Wirkungsmechanismus des Waldsterbens. Allg Forst Jagdztg 158(5/6):91-97

Göttlein A (2015) Grenzwertbereiche für die ernährungsdiagnostische Einwertung der Hauptbaumarten Fichte, Kiefer, Eiche, Buche. Allg Forst Jagdztg 186(5/6):110-116

Göttlein A, Rodenkirchen H, Häberle K, Matyssek R (2009) Nutritional effects triggered by the extreme summer 2003 in the free air ozone fumigation experiment at the Kranzberger Forst. Eur J For Res 128(2):129-134

Göttlein A, Baier R, Mellert KH (2011) Neue Ernährungskennwerte für die forstlichen Hauptbaumarten in Mitteleuropa - Eine statistische Herleitung aus van den Burg's Literaturzusammenstellung. Allg Forst Jagdztg 182(9/10):173-186 
Greve M (2014) Langfristige Auswirkungen der Waldkalkung auf Bodenzustand, Sickerwasser und Nadelspiegelwerte von drei Versuchsanlagen in Rheinland-Pfalz. Forstarchiv 85(2):35-46

Greve M, Block J, Schröck H-W, Schutze J, Werner W, Wies K (2016) Nährstoffversorgung Rheinland-Pfälzischer Wälder. Mitteilungen aus der FAWF, vol 76. Forschungsanstalt für Waldökologie und Forstwirtschaft Rheinland-Pfalz, Trippstadt

Gruber N, Galloway JN (2008) An Earth-system perspective of the global nitrogen cycle. Nature 451(7176):293-296

Guckland A, Paar U, Dammann I, Evers J, Meiwes KJ, Mindrup M (2011) Einfluss der Kalkung auf die Bestandesernährung. AFZ Wald 6:23-25

Heinsdorf D, Krauss H, Hippeli P (1988) Ernährungs-und bodenkundliche Unterschungen in Fichtenbeständen des mittleren Thüringer Waldes unter Berücksichtigung der in den letzten Jahren aufgetretenen Umweltbelastungen. Beitr Forstwirtsch 22:160-167

Helmisaari H-S (1992) Nutrient retranslocation in three Pinus sylvestris stands. For Ecol Manag 51 (4):347-367

Hippeli P, Branse C (1992) Veränderungen der Nährelementkonzentrationen in den Nadeln mittelalter Kiefernbestände auf pleistozänen Sandstandorten Brandenburgs in den Jahren 1964 bis 1988. Forstwiss Centralbl 111(1):44-60

Huber C, Weis W, Göttlein A (2006) Tree nutrition of Norway spruce as modified by liming and experimental acidification at the Höglwald site, Germany, from 1982 to 2004. Ann For Sci 63 (8):861-869

Jacob F, Andreae H (2012) Medizin für den Wald. Forstliche Bodenschutzkalkungen - Ein bundesdeutscher Überblick. Paper presented at the 1. Deutsches Kalkungssymposium, Dresden

Jacoby WG (2000) Loess: a nonparametric, graphical tool for depicting relationships between variables. Elect Stud 19(4):577-613

Jonard M, André F, Dambrine E, Ponette Q, Ulrich E (2009) Temporal trends in the foliar nutritional status of the French, Walloon and Luxembourg broad-leaved plots of forest monitoring. Ann For Sci 66(4):1-10

Jonard M, André F, Giot P, Weissen F, Perre R, Ponette Q (2010) Thirteen-year monitoring of liming and PK fertilization effects on tree vitality in Norway spruce and European beech stands. Eur J For Res 129(6):1203-1211. https://doi.org/10.1007/s10342-010-0410-3

Jonard M, Furst A, Verstraeten A, Thimonier A, Timmermann V, Potocic N, Waldner P, Benham S, Hansen K, Merila P, Ponette Q, De La Cruz AC, Roskams P, Nicolas M, Croise L, Ingerslev M, Matteucci G, Decinti B, Bascietto M, Rautio P (2015) Tree mineral nutrition is deteriorating in Europe. Glob Chang Biol 21(1):418-430. https://doi.org/10.1111/gcb.12657

Jönsson Belyazid U, Belyazid S (2012) Phosphorus cycling in boreal and temperate forest ecosystems - a review of current knowledge and the construction of a simple phosphorus model. Belyazid Consulting and Communication AB, Malmö

Kadereit JW, Körner C, Kost B, Sonnewald U (2014) Strasburger - Lehrbuch der Pflanzenwissenschaften, 37th edn. Springer Spektrum, Berlin

Khanna PK, Fortmann H, Meesenburg H, Eichhorn J, Meiwes KJ (2009) Biomass and element content of foliage and aboveground litterfall on the three long-term experimental beech sites: Dynamics and significance. In: Brumme R, Khanna PK (eds) Functioning and management of European beech ecosystems. Springer, Berlin, pp 183-205

Klaminder J, Bindler R, Emteryd O, Renberg I (2005) Uptake and recycling of lead by boreal forest plants: quantitative estimates from a site in northern Sweden. Geochim Cosmochim Acta 69 (10):2485-2496. https://doi.org/10.1016/j.gca.2004.11.013

Klemm O, Kuhn U, Beck E, Katz C, Oren R, Schulze E-D, Steudle E, Mitterhuber E, Pfanz H, Kaiser W (1989) Leaching and uptake of ions through above-ground Norway spruce tree parts. In: Schulze E-D, Lange OL, Oren R (eds) Forest decline and air pollution. Springer, Berlin, pp 210-237

Kohlpaintner M, Fäth J, Mellert KH, Blum U, Göttlein A (2017) Können einfache Extraktionsmethoden einen Beitrag zur Abschätzung des pflanzenverfügbaren Phosphors in 
Waldböden leisten?. Paper presented at the Tagung der Sektion Waldernährung im Deutschen Verband Forstlicher Forschungsanstalten (DVFFA), Gotha

Köstner B, Schupp R, Schulze E-D, Rennenberg H (1998) Organic and inorganic sulfur transport in the xylem sap and the sulfur budget of Picea abies trees. Tree Physiol 18(1):1-9

Kulhavý J, Marková I, Drápelová I, Truparová S (2009) The effect of liming on the mineral nutrition of the mountain Norway spruce (Picea abies L.) forest. J For Sci 55(1):1-8

LAF (2000) Leitfaden Forstliche Bodenschutzkalkung in Sachsen. Schriftenreihe der Sächsischen Landesanstalten für Forsten (LAF), vol 21/2000

Le Goaster S, Dambrine E, Ranger J (1990) Mineral supply of healthy and declining trees of a young spruce stand. Water Air Soil Pollut 54(1):269-280

Matson P, Lohse KA, Hall SJ (2002) The globalization of nitrogen deposition: consequences for terrestrial ecosystems. Ambio 31(2):113-119. https://doi.org/10.1639/0044-7447(2002)031[ 0113:tgondc]2.0.co;2

Meesenburg H, Ahrends B, Fleck S, Wagner M, Fortmann H, Scheler B, Klinck U, Dammann I, Eichhorn J, Mindrup M (2016) Long-term changes of ecosystem services at Solling, Germany: recovery from acidification, but increasing nitrogen saturation? Ecol Indic 65:103-112

Meiwes KJ, Khanna PK, Ulrich B (1980) Retention of sulphate by an acid brown earth and its relationship with the atmospheric input of sulphur to forest vegetation. J Plant Nutr Soil Sci 143 (4):402-411

Mellert KH, Ewald J (2014) Nutrient limitation and site-related growth potential of Norway spruce (Picea abies L. Karst) in the Bavarian Alps. Eur J For Res 133(3):433-451. https://doi.org/10. 1007/s10342-013-0775-1

Mellert KH, Göttlein A (2012) Comparison of new foliar nutrient thresholds derived from van den Burg's literature compilation with established central European references. Eur J For Res 131 (5):1461-1472. https://doi.org/10.1007/s10342-012-0615-8

Mellert K, Göttlein J (2013) Identification of nutrient thresholds and limiting nutrient factors of Norway spruce by applying new critical foliar nutrient concentrations and modern regression. Allg Forst Jagdztg 184:197-203

Mellert KH, Prietzel J, Straussberger R, Rehfuess KE, Kahle HP, Perez P, Spiecker H (2008) Relationships between long-term trends of air temperature, precipitation, nitrogen nutrition and growth of coniferous stands in Central Europe and Finland. Eur J For Res 127(6):507-524. https://doi.org/10.1007/s10342-008-0233-7

Miller HG (1986) Carbon $\times$ nutrient interactions-the limitations to productivity. Tree Physiol 2 (1-2-3):373-385

Miller HG, Cooper JM, Miller JD, Pauline OJL (1979) Nutrient cycles in pine and their adaptation to poor soils. Can J For Res 9(1):19-26

Nagel HD, Schlutow A, Scheuschner T (2014) Modellierung und Kartierung atmosphärischer Stoffeinträge und kritischer Belastungsschwellen zur kontinuierlichen Bewertung der ökosystemspezifischen Gefährdung der Biodiversität in Deutschland-PINETI (Pollutant INput and EcosysTEM Impact). Teilbericht 4 Critical Load, Exceedance und Belastungsbewertung. UBA-Texte, vol 63/2014. Umweltbundesamt, Dessau-Roßlau

Nambiar EKS, Fife DN (1991) Nutrient retranslocation in temperate conifers. Tree Physiol 9 (1-2):185-207

Nihlgård B (1985) The ammonium hypothesis: an additional explanation to the forest dieback in Europe. Ambio 14(1):2-8

Nilsson LO, Wallander H (2003) Production of external mycelium by ectomycorrhizal fungi in a Norway spruce forest was reduced in response to nitrogen fertilization. New Phytol 158 (2):409-416. https://doi.org/10.1046/j.1469-8137.2003.00728.x

Ouimet R, Moore JD, Duchesne L, Camire C (2013) Etiology of a recent white spruce decline: role of potassium deficiency, past disturbances, and climate change. Can J For Res 43(1):66-77. https://doi.org/10.1139/cjfr-2012-0344 
Övergaard R, Gemmel P, Karlsson M (2007) Effects of weather conditions on mast year frequency in beech (Fagus sylvatica L.) in Sweden. Forestry 80(5):553-563. https://doi.org/10.1093/ forestry/cpm020

Peuke A, Rennenberg H (2004) Carbon, nitrogen, phosphorus, and sulphur concentration and partitioning in beech ecotypes (Fagus sylvatica L.): phosphorus most affected by drought. Trees 18(6):639-648. https://doi.org/10.1007/s00468-004-0335-x

Piovesan G, Adams JM (2001) Masting behaviour in beech: Linking reproduction and climatic variation. Can J Bot 79(9):1039-1047

Prechtel A, Alewell C, Armbruster M, Bittersohl J, Cullen JM, Evans CD, Helliwell R, Kopácek J, Marchetto A, Matzner E (2001) Response of sulphur dynamics in European catchments to decreasing sulphate deposition. Hydrol Earth Syst Sci 5(3):311-326

Reemtsma J (1986) Der Magnesium-Gehalt von Nadeln niedersächsischer Fichtenbestände und seine Beurteilung. Allg Forst Jagdztg 157:196-200

Rennenberg H (1999) The significance of ectomycorrhizal fungi for sulfur nutrition of trees. Plant Soil 215(2):115-122

Ricke W (1960) Ein Beitrag zur Geochemie des Schwefels. Geochim Cosmochim Acta 21 (1-2):35-80

Riek W, Russ A, Hannemann J, Kallweit R (2016) Bodenzustand und Baumernährung: Kennwerte aus BZE und Level II-Programm. In: 30 Jahre forstliches Umweltmonitoring in Brandenburg. Eberswalder Forstliche Schriftenreihe, vol 63. Ministerium für Ländliche Entwicklung Umwelt und Landwirtschaft des Landes Brandenburg, Eberswalde, pp 40-60

Sardans J, Rivas-Ubach A, Penuelas J (2012) The C:N:P stoichiometry of organisms and ecosystems in a changing world: a review and perspectives. Perspect Plant Ecol Evol Syst 14(1):33-47. https://doi.org/10.1016/j.ppees.2011.08.002

Sardans J, Alonso R, Janssens IA, Carnicer J, Vereseglou S, Rillig MC, Fernandez-Martinez M, Sanders TGM, Penuelas J (2016) Foliar and soil concentrations and stoichiometry of nitrogen and phosphorous across European Pinus sylvestris forests: Relationships with climate, N deposition and tree growth. Funct Ecol 30(5):676-689. https://doi.org/10.1111/1365-2435. 12541

Scarascia-Mugnozza G, Bauer G, Persson H, Matteucci G, Masci A (2000) Tree biomass, growth and nutrient pools. In: Schulze E-D (ed) Carbon and nitrogen cycling in European forest ecosystems. Springer, Berlin, pp 49-62

Schleppi P, Tobler L, Bucher JB, Wyttenbach A (2000) Multivariate interpretation of the foliar chemical composition of Norway spruce (Picea abies). Plant Soil 219(1):251-262

Schöpp W, Posch M, Mylona S, Johansson M (2003) Long-term development of acid deposition (1880-2030) in sensitive freshwater regions in Europe. Hydrol Earth Syst Sci 7(4):436-446

Schulze ED, Lange OL, Oren R (1989) Forest decline and air pollution: a study of spruce (Picea abies) on acid soils. Springer, Berlin

Shahid M, Dumat C, Khalid S, Schreck E, Xiong TT, Niazi NK (2017) Foliar heavy metal uptake, toxicity and detoxification in plants: a comparison of foliar and root metal uptake. J Hazard Mater 325:36-58. https://doi.org/10.1016/j.jhazmat.2016.11.063

Spiecker H, Mielikäinen K, Köhl M, Skovsgaard JP (2012) Growth trends in European forests: studies from 12 countries. Springer, Berlin

Staszewski T, Lukasik W, Kubiesa P (2012) Contamination of Polish national parks with heavy metals. Environ Monit Assess 184(7):4597-4608. https://doi.org/10.1007/s10661-011-2288-z

Talkner U, Meiwes KJ, Potočić N, Seletković I, Cools N, De Vos B, Rautio P (2015) Phosphorus nutrition of beech (Fagus sylvatica L.) is decreasing in Europe. Ann For Sci 72(7):919-928. https://doi.org/10.1007/s13595-015-0459-8

UBA (2015) Daten zur Umwelt. Umwelttrends in Deutschland. Umweltbundesamt, Dessau-Roßlau

UBA (2017) Schwermetall-Emissionen. Umweltbundesamt. https://www.umweltbundesamt.de/ daten/luft/luftschadstoff-emissionen-in-deutschland/schwermetall-emissionen\#textpart-1. Accessed 07/05/2017 
Ulrich B (1981) Destabilisierung von Waldökosystemen durch Akkumulation von Luftverunreinigungen. Forst Holzwirt 36(21):525-532

van den Burg J (1985) Foliar analysis for determination of tree nutrient status: a compilation of literature data. Rijksinstituut voor Onderzoek in de Bos- en Landschapsbouw "De Dorschkamp", Wageningen

van den Burg J (1990) Foliar analysis for determination of tree nutrient status: a compilation of literature data: 2: Literature 1985-1989. "De Dorschkamp" Institute for Forestry and Urban Ecology, Wageningen

Vitousek PM, Howarth RW (1991) Nitrogen limitation on land and in the sea: how can it occur? Biogeochemistry 13(2):87-115

von Wilpert K (2003) Drift des Stoffhaushalts im Fichten-Düngeversuch Pfalzgrafenweiler. Allg Forst Jagdztg 174(2/3):21-30

von Wilpert K, Hartmann P, Schäffer J (2013) Regenerationsorientierte Bodenschutzkalkung. Merkblatt 54/2013. Forstliche Versuchs-und Forschungsanstalt Baden-Württemberg, Freiburg Waldner P, Marchetto A, Thimonier A, Schmitt M, Rogora M, Granke O, Mues V, Hansen K, Karlsson GP, Zlindra D, Clarke N, Verstraeten A, Lazdins A, Schimming C, Iacoban C, Lindroos AJ, Vanguelova E, Benham S, Meesenburg H, Nicolas M, Kowalska A, Apuhtin V, Napa U, Lachmanova Z, Kristoefel F, Bleeker A, Ingerslev M, Vesterdal L, Molina J, Fischer U, Seidling W, Jonard M, O'Dea P, Johnson J, Fischer R, Lorenz M (2014) Detection of temporal trends in atmospheric deposition of inorganic nitrogen and sulphate to forests in Europe. Atmos Environ 95:363-374. https://doi.org/10.1016/j.atmosenv.2014.06.054

Waldner P, Thimonier A, Pannatier EG, Etzold S, Schmitt M, Marchetto A, Rautio P, Derome K, Nieminen TM, Nevalainen S, Lindroos AJ, Merila P, Kindermann G, Neumann M, Cools N, de Vos B, Roskams P, Verstraeten A, Hansen K, Karlsson GP, Dietrich HP, Raspe S, Fischer R, Lorenz M, Iost S, Granke O, Sanders TGM, Michel A, Nagel HD, Scheuschner T, Simoncic P, von Wilpert K, Meesenburg H, Fleck S, Benham S, Vanguelova E, Clarke N, Ingerslev M, Vesterdal L, Gundersen P, Stupak I, Jonard M, Potocic N, Minaya M (2015) Exceedance of critical loads and of critical limits impacts tree nutrition across Europe. Ann For Sci 72 (7):929-939. https://doi.org/10.1007/s13595-015-0489-2

Wehrmann J (1959) Methodische Untersuchungen zur Durchführung von Nadelanalysen in Kiefernbeständen. Forstwiss Centralbl 78(3):77-97

Weis W, Gruber A, Huber C, Gottlein A (2009) Element concentrations and storage in the aboveground biomass of limed and unlimed Norway spruce trees at Hoglwald. Eur J For Res 128(5):437-445. https://doi.org/10.1007/s10342-009-0291-5

Open Access This chapter is licensed under the terms of the Creative Commons Attribution 4.0 International License (http://creativecommons.org/licenses/by/4.0/), which permits use, sharing, adaptation, distribution and reproduction in any medium or format, as long as you give appropriate credit to the original author(s) and the source, provide a link to the Creative Commons licence and indicate if changes were made.

The images or other third party material in this chapter are included in the chapter's Creative Commons licence, unless indicated otherwise in a credit line to the material. If material is not included in the chapter's Creative Commons licence and your intended use is not permitted by statutory regulation or exceeds the permitted use, you will need to obtain permission directly from the copyright holder.

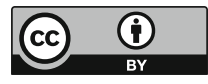

